DOI: $10.17951 /$ rh.2018.46.385-418

\author{
Jacek Pielas \\ (Uniwersytet Jana Kochanowskiego w Kielcach) \\ https://orcid.org/0000-0002-7165-8905
}

\title{
Akt ostatniej woli Anny ze Stanisławskich Zbąskiej, pierwszej polskiej poetki, z 7 lipca 1696 roku
}

\author{
The Act of Anna from Stanisławski Zbqiska's Last Will, \\ the First Polish Female Poet, on 7 July 1696
}

\section{STRESZCZENIE}

Przedmiotem edycji źródłowej jest nieznany dotąd testament Anny ze Stanisławskich Zbąskiej, pierwszej polskiej poetki, z 7 lipca 1696 r. Anna Stanisławska, autorka dzieła Transakcyja albo opisanie całego życia jednej sieroty przez żałosne treny od tejże samej pisane roku 1685, nie posiada dotąd szczegółowej biografii. Publikowany testament przynosi nowe informacje na temat ostatnich lat życia poetki i jej działalności na rzecz Kościoła katolickiego, a także posiadanego przez nią majątku. Testament wskazuje nieznane dotąd miejsce pogrzebu poetki w Lublinie. Jednocześnie akt ostatniej woli Anny Stanisławskiej ukazuje jej szczodrość wobec wielu instytucji Kościoła katolickiego.

Słowa kluczowe: testament, Anna ze Stanisławskich Zbąska, pierwsza poetka, biografia, Kościół katolicki

Postać Anny ze Stanisławskich Zbąskiej, uznawanej przez wielu badaczy dziejów literatury za pierwszą polską poetkę, autorki dzieła Transakcyja albo opisanie całego życia jednej sieroty przez żałosne treny od tejże samej pisane roku 1685, wielokrotnie budziła zainteresowanie historyków literatury, historyków sztuki i historyków. Od czasu odkrycia przez Aleksandra Brücknera pod koniec XIX w. autografu Transakcyi ${ }^{1}$, a następnie jego wydania przez Idę Kotową w 1935 r. ${ }^{2}$, o osobie Anny ze Stanisławskich

1 A. Brückner, Pierwsza autorka polska i jej autobiografia wierszem, „Biblioteka Warszawska" 1893,4 , s. 424-429.

2 A. Stanisławska, Transakcyja albo opisanie całego życia jednej sieroty przez żałosne treny od tejże samej pisane roku 1685, wyd. I. Kotowa, w: Biblioteka Pisarzów Polskich, nr 85, Kraków 1935. Należy odnotować, że w 2003 r. w ramach serii „Klasyka mniej znana” Piotr 
Zbąskiej napisano już niemało. Wśród prac poświęconych poetce dominują opracowania odnoszące się do treści jej dzieła oraz stanowiące analizę jej umysłowości, warsztatu poetyckiego i kontekstu obyczajowego funkcjonowania kobiety w środowisku szlacheckim drugiej połowy XVII w. Należy dodać, że w większości tych prac opowieści o życiu poetki oparte zostały przede wszystkim na wspomnianej autobiografii i ustaleniach dokonanych przez A. Brücknera i I. Kotową ${ }^{3}$. W związku z zachowaniem się

Borek wydał fragmenty dzieła Anny Stanisławskiej na podstawie edycji I. Kotowej (A. Stanisławska, Transakcyja albo Opisanie całego życia jednej sieroty przez żałosne treny od tejże samej pisane roku 1685. Fragmenty, oprac. P. Borek, Kraków 2003 - wydanie bez aparatu naukowego i wstępu), zaś w 2013 r. ukazała się dwujęzyczna edycja wybranych trenów (treny 1-29). Zob. A. Stanisławska, A Transaction, or an Account of the Entire Life of an Orphan Girl by Way of Plaintful Threnodies in the Year 1685. The Aesop Episode, tłum., wstęp i oprac. B. Keane, Warszawa 2013.

3 Zob. A. Brückner, Pierwsza autorka polska; idem, Dzieje literatury polskiej w zarysie, t. 1, Warszawa 1908, s. 365-367; I. Kotowa, Anna Stanisławska, pierwsza autorka polska, „Pamiętnik Literacki" 1934, 31, s. 267-290 i następnie: T. Mikulski, Anna Zbąska ze Stanistawskich, „Ruch Literacki" 1935, 10, s. 202-203; Z. Kuchowicz, Wizerunki niepospolitych niewiast staropolskich XVI-XVII wieku, Łódź 1972, s. 278-279; A. Sajkowski, Staropolska miłość. Z dawnych listów i pamiętników, Poznań 1981, s. 11-24; idem, Żywoty niepospolitych kobiet polskiego baroku, Łódź 1989, s. 98-113; K. Targosz, Sawantki w Polsce XVII w. Aspiracje intelektualne kobiet ze środowisk dworskich, Warszawa 1997, s. 280-313; eadem, Damy XVII wieku z piórem w ręku - od listu do autobiografii, w: Pisarki polskie epok dawnych, red. K. Stasiewicz, Olsztyn 1988, s. 28-33; S. Szczęsny, Anny ze Stanistawskich Zbaskiej opowieść o sobie i mężach. Glosa do barokowej trenodii, w: ibidem, s. 69-87; H. Popławska, "Żałosne treny" Anny Stanisławskiej, w: ibidem, s. 89-111; H. Dziechcińska, Pamiętniki czasów saskich. Od sentymentalizmu do sensualizmu, Bydgoszcz 1999, s. 45-47; K. Stasiewicz, Zmysłowa i elokwentna prowincjuszka na staropolskim Parnasie. Rzecz o Elżbiecie Drużbackiej i nie tylko..., Olsztyn 2001, s. 20, 33-34; H. Dziechcińska, Świat i człowiek w pamiętnikach trzech stuleci: XVI-XVII-XVIII, Warszawa 2003, s. 91-92; H. Wiśniewska, Świat ptci żeńskiej baroku zaklęty w stowach, Lublin 2003 (według indeksu). Wszystkie wymienione wyżej opracowania oraz wiele drobniejszych, niejednokrotnie popularnonaukowych tekstów na temat Anny Zbąskiej zebrał i omówił dokładniej Dariusz Rott w jednym z rozdziałów książki poświęconej poetce, co zwalnia w tym miejscu z przywoływania ich wszystkich. Zob. D. Rott, Kobieta z przemalowanego portretu. Opowieść o Annie Zbaskiej ze Stanisławskich i jej Transakcyji albo Opisaniu całego życia jednej sieroty [...], Katowice 2004, s. 164-167 (bibliografia), 31-45 (rozdział Stan badań). Zob. także ostatnio: J. Partyka, "Żona wyćwiczona”. Kobieta pisząca w kulturze XVI i XVII wieku, Warszawa 2004, s. 150-151; J. Kusiak, "Jedna sierota" w sarmackim świecie - autoportret Anny Stanisławskiej, w: Gorsza "kobieta": dyskursy, inności, samotności, szaleństwa, red. D. Adamowicz, Y. Anisimovets, O. Taranek, Wrocław 2008, s. 211-221; E.E. Wróbel, Staropolski autoportret białogłowy, „Folia Historica Cracoviensia” 2011, 17, s. 137-150; M. Ożarska, Combining a Lament with a Verse Memoir. Anna Stanisławska's Transaction' (1685), "Časopis pro slovanskou filologii" 2012, 81, 4, s. 389-404; A. Araszkiewicz, Wierszowany pamiętnik Anny Stanistawskiej, w: Per mulierem... Kobieta w dawnej Polsce - w średniowieczu i w dobie staropolskiej, red. K. Justyniarska-Chojak, S. Konarska-Zimnicka, Warszawa 2012, s. 151-160; R. Krzywy, Pragnienie pamięci i „białogłowski koncept”. Kilka uwag o świadomości warsztatowej pierwszych polskich pamiętnikarek (Anna Zbaska, Regina Salomea Pilsztynowa), „Śląskie Studia Polonistyczne" 2013, 2, s. 119-141; A.T. Staniszewski, Nieobecna „książka białogłowskiego kon- 
do dziś trzech wizerunków poetki, na temat poświęconych jej obrazów wypowiedzieli się również historycy sztuki. Natomiast w zakresie badań typowo historycznych nad biografią poetki - genealogią rodziny, biegiem jej życia, działalnością fundacyjną - z pewnością pozostaje jeszcze wiele do zrobienia.

Jak już wspomniano, podstawowe fakty odnoszące się do biografii poetki ustalone zostały przez odkrywcę jej dzieła, a następnie znacząco uzupełnione przez I. Kotową ${ }^{5}$. Znaczenie ustaleń tejże badaczki jest nie do przecenienia, zważywszy że nie poprzestała ona jedynie na analizie informacji zawartych w autobiografii Anny Zbąskiej i wykorzystała także źródła historyczne, m.in. akta grodzkie stężyckie oraz wyroki Trybunału Koronnego, a więc źródła, którymi dziś już niestety nie dysponujemy ${ }^{6}$. Następnie część badaczy zajmujących się postacią Anny Stanisławskiej poszerzała wiedzę o życiu poetki o kolejne, zazwyczaj pojedyncze szczegóły z jej życia. Większość tych faktów zebrał w 2004 r. Dariusz Rott w jednym z rozdziałów swej książki ${ }^{7}$. Wypada dodać, że nie zostało wówczas zauważone wydawnictwo źródłowe piszącego te słowa, który w 2000 r. opublikował - wraz z komentarzem - tekst intercyzy przedślubnej spisanej 10 października 1669 r. w Krakowie w związku z zawarciem małżeństwa przez poetkę z Janem Zbigniewem Oleśnickim, podkomorzycem sandomierskim. Publikacja ta wnosi nowe szczegóły, dotyczące zwłaszcza spraw majątkowych i jednego z małżeństw Stanisławskiej. Wiele nowych informacji, szczególnie dotyczących kwestii majątkowych, małżeństwa Anny ze wspomnianym podkomorzycem sandomierskim oraz okresu

ceptu”. Kobiety, kanon i badania literatury dawnej, „Terminus” 2014, 16, 2, s. 193-212; K. Obremski, O „kobietach, kanonie i badaniach literatury dawnej" głos polemiczny, „Terminus" 2016, 18, 3, s. 271-286; K. Zielińska, O trenach Anny Stanisławskiej. Refleksja genologiczna, „Szkice Humanistyczne" 2016, 16, 3, s. 25-36.

4 Zob. J. Ruszczycówna, Trzy portrety polskiej poetki XVII wieku (Anna ze Stanisławskich Zbaska), „Rocznik Muzeum Narodowego w Warszawie” 1969, 13, s. 321-363; J. Bursze, Anna Zbąska ze Stanistawskich, ibidem, s. 365-374. Por. D. Rott, op. cit., s. 168-169 (spis reprodukcji portretów poetki).

5 Por. przyp. 1-3.

6 Zob. przede wszystkim: M. Stankowa, Ocalałe fragmenty akt Trybunału Koronnego Lubelskiego w Wojewódzkim Archiwum Państwowym w Lublinie 1578-1793, "Archeion” 1964, 40, s. 105-129 oraz ostatnio Deputaci Trybunatu Koronnego 1578-1794. Spis, cz. I: 1578-1620, oprac. H. Gmiterek, Warszawa 2017, s. 33-34.

7 D. Rott, op. cit., s. 46-61. Na wyróżnienie zasługują z pewnością ustalenia poczynione przez Karolinę Targosz, która w pracy poświęconej kronikarkom zakonnym w XVII w. podała kilka cennych informacji na temat związków poetki z karmelitankami bosymi z Warszawy i Lublina. Zob. K. Targosz, Piórem zakonnicy. Kronikarki w Polsce XVII w. o swoich zakonach i swoich czasach, Kraków 2002, s. 165, 167-168, 278.

8 J. Pielas, Zabezpieczenie praw majątkowych Anny Stanisławskiej w intercyzie przedślubnej z 1669 roku, "Almanach Historyczny" 2000, 2, s. 209-217. 
wdowieństwa po nim autor niniejszego opracowania zawarł w wydanej w 2007 r. monografii rodziny Oleśnickich9 . Niewątpliwie istotne znaczenie dla ukazania środowiska rodzinnego poetki ma także fakt opublikowania na łamach Polskiego Słownika Biograficznego biogramu jej ojca, Michała Stanisławskiego (zm. 1668), chorążego halickiego (1650-1663), kasztelana sądeckiego (1663-1665) i wojewody kijowskiego (1665-1668) ${ }^{10}$.

Podawany obecnie do druku testament Anny ze Stanisławskich Zbąskiej nie był dotychczas znany, a w związku z niesłabnącym zainteresowaniem badaczy tą postacią z pewnością wart jest opublikowania. Na tle innych staropolskich aktów ostatniej woli wprawdzie nie wyróżnia się szczególnie (m.in. brak w nim podsumowania życia, odniesień do stosunków z trzema mężami czy też szerszej prezentacji uczuć religijnych), niemniej jednak z uwagi na znaczną ilość informacji o życiu poetki zdecydowano o jego uprzystępnieniu drukiem. O fakcie spisania testamentu przez Annę Stanisławską wiedzieliśmy dotąd z przekazów pośrednich, przede wszystkim informacji podanych przez I. Kotowa która czytała istniejące jeszcze przed wojną akta Trybunału Koronnego. W aktach tych znajdowała się złożona 2 czerwca 1701 r. skarga krewnego i potencjalnego sukcesora poetki - Jana Aleksandra Koniecpolskiego (zm. 1719), koniuszego koronnego (1692-1704), następnie wojewody bracławskiego (1704-1710) i sieradzkiego (1710-1719). Według I. Kotowej skarga zawierała informację, że gdy umierająca poetka leżała w domu jakiegoś Żyda w Kurowie „służąca jej, Olszowska, z namowy prebendarza z kongregacji misjonarzy, zamknęła drzwi i pootwierała skrzynie i szkatuły, złoto, klejnoty, gotówkę oraz testament podkomorzynej lubelskiej [podkr. - J.P.] wydała prebendarzowi kurowskiemu, ten zaś odwiózł to wszystko Tarle [Michałowi Bartłomiejowi Tarle (1656-1715), proboszczowi parafii Św. Krzyża w Warszawie (1685-1709), następnie biskupowi poznańskiemu (1710-1715) - J.P.]"11. W następstwie tej skargi oraz próby obalenia przez Koniecpolskiego zapisów testamentowych Anny doszło do wszczęcia przez niego procesów sądowych ze Zgromadzeniem Księży Misjonarzy w Warszawie ${ }^{12}$.

Publikowany akt ostatniej woli Anny Stanisławskiej w sposób istotny uzupełnia wiedzę na temat postaci pierwszej polskiej poetki. Przede wszystkim jest on drugą po autobiografii (pomijając jeden odnaleziony

9 Idem, Oleśniccy herbu Dębno w XVI-XVII wieku. Studium z dziejów zamożnej szlachty doby nowożytnej, Kielce 2007, szczególnie s. 352-357, 394-398.

${ }_{10}$ M. Nagielski, Stanisławski Michał, w: Polski Słownik Biograficzny [dalej: PSB], t. 42, Warszawa-Kraków 2003-2004, s. 120-124.

11 I. Kotowa, op. cit., s. 276-277.

12 Ibidem. 
dotąd list Stanisławskiej) ${ }^{13}$ „,wypowiedzią osobistą" poetki, gdyż tak należy rozumieć przekaz testamentów doby staropolskiej ${ }^{14}$. Odnalezione źródło jest oryginałem testamentu, pod którym widnieje podpis poetki (fot. 1) - mamy więc do czynienia z drugim znanym własnoręcznym podpisem Zbąskiej (jak wiadomo, na podstawie wspomnianego wyżej listu z podpisem Stanisławskiej ustalono, że jej dzieło jest autografem) ${ }^{15}$.

Testament przynosi wiele informacji na temat ostatnich lat życia Anny. Jak dotąd bowiem wiedzę o okresie życia poetki po napisaniu przez nią Transakcyi, a więc o latach 1685-1701, należy uznać za skromną. W literaturze poświęconej A. Zbąskiej podkreślano jej zaangażowanie w prowadzenie interesów majątkowych (jednak z reguły bez informacji o czynionych przez nią transakcjach) i procesów prawnych, a także w działalność fundacyjną na rzecz różnych instytucji Kościoła katolickiego. I tak dla 1688 r. poświadczony jest zajazd Stanisławskiej na dwór w miejscowości Wielgie (województwo sandomierskie, powiat radomski), będący w posiadaniu niejakiej Promieńskiej ${ }^{16}$. Według D. Rotta w 1690 r. poetka zakończyła wznoszenie murowanego kościoła w Kurowie w Lubelskiem, miasteczku trzeciego jej męża - Jana Bogusława Zbąskiego (zm. w listopadzie 1683), chorążego (1664-1678) i podkomorzego lubelskiego (1678-1683) ${ }^{17}$. W Księdze pamiatkowej trzechsetlecia Zgromadzenia Księży Misjonarzy (162517/IV-1925) znajduje się informacja, że:

Dom lubelski Księży Misjonarzy zawdzięczał swoje powstanie p. Annie Zbąskiej, która jeszcze w r. 1698 ofiarowała ks. Wizytatorowi Bartłomiejowi Tarle swe dobra Maciejowice w tym celu, aby służyły na założenie domu Księży Misjonarzy w Lublinie. W r. 1700 ofiarowała ta sama pani pewną sumę pieniężną na zakupienie domu mieszkalnego dla Księży Misjonarzy ${ }^{18}$.

Na podstawie kroniki karmelitanek bosych warszawskich Karolina Targosz ustaliła, że poetka zapisała tymże karmelitkom „dworek z gruntem na Glinkach" w Warszawie, spłaciła dom pewnego rzeźnika i na nowy kościół przeznaczyła 10000 zł. Przez pewien czas użytkowała mieszkanie

13 Ibidem, s. 274-275.

14 Por. m.in.: Testamenty szlachty krakowskiej XVII-XVIII w. Wybór tekstów źródłowych $z$ lat 1650-1799, oprac. A. Falniowska-Gradowska, Kraków 1997, Wstęp, s. V, VIII; Cui contingit nasci, restat mori. Wybór testamentów z województwa sandomierskiego, oprac. M. Lubczyński, J. Pielas, H. Suchojad, Warszawa 2005, Wstęp, s. 7.

15 I. Kotowa, op. cit., s. 267-268, 274-276.

16 Ibidem, s. 274-276. Por. D. Rott, op. cit., s. 52-54.

17 D. Rott, op. cit., s. 54.

18 Księga pamiatkowa trzechsetlecia Zgromadzenia Księży Misjonarzy (1625-17/IV-1925), Kraków 1925, s. 102. 
po Helenie Lubomirskiej przy tymże klasztorze ${ }^{19}$. Ponadto ze wspomnianego listu Zbąskiej z 23 maja 1699 r. do przyjaciela rodziny Stanisławskich - Franciszka Bienieckiego, cześnika żydaczowskiego (1689-1697) wynika, że w związku z traktatem karłowickim szykowała się do wyjazdu na południowo-wschodnie tereny Rzeczypospolitej celem objęcia dóbr ojcowskich, przez wiele lat pozostających pod zwierzchnictwem tureckim ${ }^{20}$.

Przekaz testamentu pozwala określić stan posiadania dziedzicznych dóbr ziemskich Zbąskiej przed śmiercią. Wiadomo przy tym, że niemałą część nieruchomości, w tym odziedziczonych po matce, zbyła wcześniej ${ }^{21}$. W chwili śmierci - stosownie do przekazu klauzul testamentowych - w jej dyspozycji pozostawały następujące dobra ziemskie: majętność maciejowicka w województwie sandomierskim, powiecie stężyckim (miasteczko Maciejowice z 14 wsiami i folwarkiem Grochałka), wsie Borków, Skaryszówek Mniejszy i Chrostów w województwie i powiecie kaliskim, połowa wsi Odrana Wola w województwie mazowieckim, ziemi warszawskiej, powiecie błońskim oraz dworek na terenie Lublina. Ponadto posiadała prawo dziedziczne do dóbr ojcowskich w województwie podolskim (Dunajgród, Hozołubińce, Rzeczyńce).

Nie jest znana data śmierci Anny Zbąskiej i należy podkreślić, że publikowany testament nic w tej kwestii nie wnosi, ponieważ spisany został kilka lat przed jej śmiercią. Przybliżony termin zgonu poetki oraz jego okoliczności omówiła przed laty I. Kotowa na podstawie wspomnianej wyżej skargi Jana Koniecpolskiego z 2 czerwca 1701 r. Opierając się na tym źródle, uznała, że śmierć Zbąskiej nastąpiła wiosną 1701 r. ${ }^{22}$ Dotychczasowe poszukiwania źródłowe piszącego te słowa również nie zaowocowały ustaleniem daty śmierci autorki Transakcyi. Wiadomo, że jeszcze w $1700 \mathrm{r}$. przeprowadzała transakcje majątkowe, m.in. zastawiając swe dobra w Kaliskiem: wieś Skarszewek ks. Marcinowi Feliksowi Gałęskiemu, kanonikowi łuckiemu, proboszczowi siemiatyckiemu za 20000 zł, zaś wieś Borków Stanisławowi Żórawskiemu, pułkownikowi królewskiemu². Z przekazu I. Kotowej wynika, że 14 października tego roku w grodzie stężyckim doszło do zatwierdzenia jej testamentu datowanego w Maciejowicach. Nie-

19 K. Targosz, Piórem zakonnicy, s. 164-165, 168, 278.

20 I. Kotowa, op. cit., s. 274-275; Urzędnicy województwa ruskiego XIV-XVIII wieku (ziemie halicka, lwowska, przemyska, sanocka). Spisy, oprac. K. Przyboś, Wrocław 1987 [dalej: UrzRus.], s. 168.

21 Zob. J. Pielas, Zabezpieczenie praw majątkowych, s. 213.

22 I. Kotowa, op. cit., s. 277.

23 Biblioteka Polskiej Akademii Nauk w Kórniku, Teki Dworzaczka. Materiaty historyczno-genealogiczne do dziejów szlachty wielkopolskiej XV-XX wieku, kier. nauk. J. Wisłocki, Kórnik-Poznań 2004 (online). 
stety, wspomniana badaczka nie podała, czy czynność ta została dokonana przez samą Annę, czy też upoważnioną do tego osobę; nie zaznaczyła też jednak, że doszło do aprobacji testamentu już po śmierci testatorki ${ }^{24}$. Wobec braku, jak dotąd, późniejszych przekazów o życiu A. Zbąskiej należy uznać, że zmarła między 14 października 1700 r. a 2 czerwca 1701 r. Hipoteza I. Kotowej, że śmierć nastąpiła wiosną 1701 r. wydaje się wielce prawdopodobna - zapewne bowiem Jan Koniecpolski starał się jak najszybciej wnieść do akt trybunalskich skargę przeciwko działaniom Bartłomieja Michała Tarły względem majątku zmarłej ${ }^{25}$.

Z treści testamentu dowiadujemy się, że decyzję o jego sporządzeniu poetka podjęła, będąc w dobrym zdrowiu, „wcześnie jednak dla wszelakich przypadków, które na życie ludzkie niespodzianie przychodzić zwykły [...]". Postanowiła, by po śmierci jej ciało, obleczone w habit karmelitanek bosych, pochowane zostało w należącym do karmelitanek kościele pw. Niepokalanego Poczęcia NMP w Lublinie. Jest to jedyna jak dotąd informacja o miejscu ostatniego spoczynku Anny ze Stanisławskich Zbąskiej, trudna wszakże do potwierdzenia z uwagi na zniszczenie metryk i innych dokumentów tegoż klasztoru ${ }^{26}$. Należy zaznaczyć, że pochówek w habicie, fakt pomieszkiwania przez pewien czas przy klasztorze Karmelitanek warszawskich i wymienienie jej na kamieniu węgielnym kościoła tegoż klasztoru może wskazywać, że poetka była tercjarką karmelitańską.

Pogrzeb Anny Zbąskiej miał być odprawiony za sumę 100 czerwonych zł. Na msze święte za swoją duszę przeznaczyła z posiadanej gotówki 10000 zł, a ponadto 1000 zł na jałmużnę dla ubogich oraz 500 zł dla ubogich sierot w szpitalu Św. Marcina w Warszawie, pozostającym pod zarządem szarytek. Jeśli chodzi o modlitwy za swą duszę, poetka uczyniła jeszcze jeden legat - kościołowi w rodowych Maciejowicach zapisała bowiem 3000 zł z obowiązkiem odprawiania jednej mszy świętej tygodniowo przed obrazem Najświętszej Marii Panny oraz dorocznego aniwersarza.

Dominująca część testamentu poświęcona została dyspozycjom odnoszącym się do posiadanego przez poetkę majątku ziemskiego i dóbr ruchomych. Anna Zbąska wyraźnie określiła sytuację związaną z dziedziczeniem majątku po swej śmierci. Przypomniała, że nie doczekała się potomstwa, jedyny jej bliższy spadkobierca z linii ojcowskiej - wspomniany wyżej brat cioteczny Jan Aleksander Koniecpolski, koniuszy koronny - był sukcesorem wielkiej fortuny Koniecpolskich ( $w$ tym po hetmanie

24 I. Kotowa, op. cit., s. 276.

25 Ibidem, s. 277.

26 Zob. M. Borkowska OSB, Leksykon zakonnic polskich epoki przedrozbiorowej, t. 2: Polska Centralna i Południowa, Warszawa 2005, s. 359 (tu literatura przedmiotu). 
wielkim koronnym Stanisławie Koniecpolskim)27, a nadto w linii macierzystej - po Szyszkowskich - posiadała jedynie bardzo dalekich krewnych. W związku z powyższym uznała, że całość swych dóbr ziemskich i ruchomych przeznacza na - jak zaznaczyła - „Dawcę tychże dóbr, to jest Boga i Odkupiciela mego Chrystusa Jezusa [...]”. Wyraźnie zobowiązała przy tym egzekutorów ostatniej woli (zob. dalej), aby nie pozwolili nikomu, a więc przede wszystkim krewnym, partycypować w spadku po niej. Jeśli chodzi o krewnych, uczyniła wobec nich w tym względzie drobne ustępstwa w rozporządzeniu majątkiem. Dla Jana Koniecpolskiego przeznaczyła - jak stwierdziła: „[...] z afektu [...] siestrzeńskiego” - sumę 20000 zł, zaś dalszym krewnym z familii Szyszkowskich łącznie 6000 zł. Wśród innych osób obdarzonych legatami pieniężnymi widzimy także Franciszka Miaskowskiego, pisarza grodzkiego konińskiego, oraz grono służby, w tym wymienione $\mathrm{z}$ imienia lub nazwiska kobiety należące do jej dworu, a także „drobniejszą czeladź”.

W zakresie dóbr ruchomych i nieruchomych podała jasną wskazówkę co do ich losów po swej śmierci. Stwierdzając, że z uwagi na trwające bezkrólewie po zgonie Jana III Sobieskiego i związane z nim zamknięcie grodów nie miała możliwości prawnego wyznaczenia jednej osoby do rozporządzenia majątkiem, losy swych dóbr złożyła w ręce sześciu egzekutorów testamentu: powinowatego Jana Stanisława Zbąskiego, biskupa warmińskiego (1688-1697), Karola Tarły, podkanclerzego koronnego (1689-1702), Stanisława Szembeka, sufragana i oficjała krakowskiego (1690-1696), brata ciotecznego Jana Aleksandra Koniecpolskiego, koniuszego koronnego (1692-1704), Bartłomieja Tarły, proboszcza kościoła Świętego Krzyża w Warszawie (1685-1709) i Franciszka Miaskowskiego, pisarza grodzkiego konińskiego (1686-1696). Wymienieni wykonawcy ostatniej woli zostali zobowiązani do objęcia jej dóbr dziedzicznych i jak najszybszego dokonania ich sprzedaży po jej śmierci. Uzyskana w ten sposób gotówka miała być przeznaczona prawie wyłącznie (por. wyżej) na legaty pobożne. W związku z faktem, że w testamencie poetka wymieniła szacunkową wartość swych dóbr ziemskich na podstawie proponowanych jej niegdyś sum przez chętnych do zakupu majętności, możemy określić w przybliżeniu, że pod koniec życia dysponowała majątkiem o wartości ok. 400000 zł, nie licząc bardzo cennych bez wątpienia ruchomości. O tych ostatnich wiemy niewiele poza mobiliami wymienionymi jako legaty dla karmelitanek lubelskich przy kościele Niepokalanego Poczęcia NMP oraz 14 obrazami z jej kolekcji, którymi obdarowała egzekutorów w ramach

${ }^{27}$ J.A. Gierowski, Koniecpolski Jan Aleksander, w: PSB, t. 13, Wrocław-Warszawa-Kraków 1967-1968, s. 520-521. 
wdzięczności za ich przyszłe starania przy realizacji testamentu. Niestety, wzmiankowany przez A. Zbąską osobny rejestr ruchomości, który wkrótce po spisaniu testamentu miał zostać sporządzony, nie został dotychczas odnaleziony.

$\mathrm{Na}$ jakie cele pobożne przeznaczyła poetka największe sumy? Sumę 100000 zł ofiarowała na odnowienie kościołów należących do biskupstwa wileńskiego, po 50000 zł na zgromadzenia księży misjonarzy w Lublinie (w tym na seminarium dla 6 kleryków) i w Warszawie (m.in. na wybudowanie szpitala dla ubogich). Temu ostatniemu zgromadzeniu legowała również 10000 zł na pokrycie należącej do niego kaplicy kościoła Swiętego Krzyża.

W sposób szczególny - ze względu na pragnienie pochówku u karmelitanek lubelskich w kościele Niepokalanego Poczęcia NMP - A. Zbąska potraktowała legaty na rzecz tego domu. Oprócz wspomnianych już 100 czerwonych zł na pogrzeb, poetka ofiarowała „Poczętkom” także drogocenne ruchomości o wartości 10000 zł na dokończenie budowy kościoła. Wspomniała również o dokonanym wcześniej - zapewne przez nią samą - zapisie 2000 zł na rzecz tegoż klasztoru na wsi Godzisz (województwo sandomierskie, powiat stężycki) z przeznaczeniem na posag dla jednej $\mathrm{z}$ sióstr.

Po 20000 zł uzyskały od niej karmelitanki lubelskie przy kościele Św. Józefa oraz lubelskie szarytki, którym oprócz pieniędzy A. Zbąska darowała dworek w Lublinie.

Legaty w wysokości 10000 zł przypadły benedyktynkom radomskim, koletkom krakowskim, kolegium pijarów w Warszawie, karmelitankom bosym na planowaną fundację domu w Przemyślu oraz tymże karmelitankom poznańskim wraz z 1000 zł posagu dla jednej z sióstr, wreszcie dominikanom lwowskim, którzy zostali zobowiązani do odprawiania dwóch mszy tygodniowo i aniwersarza za duszę ojca poetki oraz jej antenatów.

Kilkutysięczne legaty Anna ze Stanisławskich Zbąska przeznaczyła dla pijarów krakowskich (5000), franciszkanek (4000) i bernardynek kaliskich (3000), bernardynek w Brześciu Litewskim (3000), wizytek warszawskich na planowaną świątynię (3000) oraz kapucynów krakowskich na wspomożenie zapoczątkowanej przez nich fundacji (3000). Drobniejsze sumy uzyskali ponadto reformaci krakowscy (1000), franciszkanie stężyccy (1000), bernardyni w Kaliszu (700) i na Górze Kalwarii (500) oraz kanonicy regularni przy kościele Św. Mikołaja w Kaliszu (500).

Poetka zadbała o doposażenie kilku kościołów - zarówno tych położonych w jej dziedzicznych dobrach, jak i w dobrach mężowskich. I tak kościołowi w rodowym Borkowie zapisała łącznie 6000 zł, kościołowi 
w Maciejowicach łącznie 7000 zł i osobno szpitalowi w tejże miejscowości przy kościółku Zwiastowania NMP 6000 zł, ponadto do zapisu matczynego na rzecz kościoła we Wrzeszczowie dodała 500 zł. Kościołowi parafialnemu w Tarłowie, miasteczku drugiego jej męża - Jana Zbigniewa Oleśnickiego (zm. 1674/1675), podkomorzyca sandomierskiego, zapisała 3000 zł, zobowiązując rządców świątyni do odprawiania jednej mszy tygodniowo i aniwersarza za jego duszę. Kościołowi w Kurowie, znajdującemu się w dobrach trzeciego małżonka - Jana Bogusława Zbąskiego (zm. w listopadzie 1683), podkomorzego lubelskiego (1678-1683), przeznaczyła natomiast $4000 \mathrm{zł}$.

Tak znaczna liczba wysokich legatów na cele pobożne wiązała się z charakterystycznymi przejawami staropolskiej religijności. Legaty i zapisy testamentowe $\mathrm{w}$ świadomości ówczesnych ludzi zapewnić miały zbawienie, ulżenie duszy ze względu na popełnione grzechy, zadośćuczynienie dawnym obietnicom. Do tego dochodził element kommemoratywny, związany z chęcią zaznaczenia swego udziału we wspomożeniu instytucji kościelnych. Nie bez znaczenia w przypadku poetki był również fakt, że nie miała ona potomstwa i bliskich krewnych, a zatem gros swego majątku mogła poświęcić na cele pobożne ${ }^{28}$.

W swoim testamencie Anna Zbąska zawarła także wytyczne co do losów dóbr ojcowskich na południowym wschodzie Rzeczypospolitej, w 1696 r. pozostających jeszcze w rękach tureckich. Wskazała wyraźnie, aby w przypadku odzyskania przez Rzeczpospolitą tych terenów ojcowizna została sprzedana, zaś uzyskana w ten sposób gotówka podzielona na dwie części: połowa pieniędzy - stosownie do woli ojcowskiej - miała wspomóc ufundowany przez niego szpital dla rannych żołnierzy w Kamieńcu Podolskim, natomiast druga połowa miała zostać przeznaczona na odbudowę kościołów i klasztorów w ojcowskim Dunajgrodzie i królewskim Kamieńcu Podolskim.

Analogicznie do wielu testamentów staropolskich również w publikowanym akcie ostatniej woli znajdujemy stwierdzenie o możliwości zmiany w przyszłości zapisów testamentowych przez testatorkę. Warto przy

28 Zob. m.in.: B. Popiołek, Woli mojej ostatniej testament ten... Testamenty staropolskie jako źródło do historii mentalności XVII i XVIII wieku, Kraków 2009, s. 158-196; eadem, „Na ratunek duszy mojej" - pobożne fundacje w świetle testamentów staropolskich XVII-XVIII wieku, w: Mecenas i fundator. Magnateria Rzeczypospolitej XVI-XVIII wieku, red. E. Dubas-Urwanowicz, J. Urwanowicz, Białystok 2011, s. 43-60; eadem, Polisa na życie wieczne. Zagadnienie miłosierdzia w testamentach czasów saskich, "Nasza Przeszłość” 2012, 117, s. 143-156; A. Karpiński, Zapisy "pobożne" i postawy religijne mieszczanek polskich w świetle testamentów z drugiej połowy XVI i XVII w., w: Tryumfy i porażki. Studia z dziejów kultury polskiej XVI-XVIII w., red. M. Bogucka, Warszawa 1989, s. 203-234. 
tym zwrócić uwagę, jak się wydaje, na końcowy akapit aktu ostatniej woli A. Zbąskiej. W związku z przekazaniem niemal całości dóbr Kościołowi katolickiemu i jego instytucjom, być może w przewidywaniu reakcji jej naturalnego spadkobiercy - Jana Aleksandra Koniecpolskiego, koniuszego koronnego, poetka zastrzegła, iż w przypadku gdyby doszło do stwierdzenia nieważności sporządzonego przez nią testamentu, należy go potraktować jako kodycyl. Jak wiadomo, codicillus, czyli „rozporządzenie ostatniej woli nie ustanawiające dziedzica" ${ }^{29}$, sporządzany był niejednokrotnie w owym czasie jako dodatek czy też uzupełnienie właściwego testamentu i zawierał dyspozycje o charakterze majątkowym ${ }^{30}$.

Czy Anna ze Stanisławskich Zbąska sporządziła w następnych latach kolejny akt ostatniej woli lub też odmieniła po 1696 r. swe dyspozycje testamentowe? Nic o tym, jak dotąd, nie wiadomo. Z informacji, że 14 października 1700 r. w grodzie stężyckim został zaaprobowany jej testament spisany w Maciejowicach (zob. wyżej) można ostrożnie wnosić, iż chodziło właśnie o publikowany obecnie akt ostatniej woli poetki. Ponadto znane dotychczas działania Bartłomieja Tarły, proboszcza kościoła Św. Krzyża w Warszawie, który niewątpliwie realizował przynajmniej część dyspozycji testamentowych poetki (zob. wyżej), wskazują na to, że wypełniał jej wolę zawartą w podawanym do druku akcie ostatniej woli z 7 lipca $1696 \mathrm{r}$.

Publikowany testament odnaleziony został w jednej z części dawnego archiwum podhorodeckiego, a więc archiwaliów różnych rodzin magnackich zgromadzonych niegdyś w Podhorcach, dziś zaś przechowywanych w Archiwum Narodowym w Krakowie (oddział na Wawelu). Akt ostatniej woli Anny Zbąskiej znajduje się w obrębie dokumentów odnoszących się bezpośrednio do postaci Jana Aleksandra Koniecpolskiego, koniuszego koronnego. Niewątpliwie żywo zainteresowany dziedzictwem po poetce, a nadto wyznaczony na jednego z egzekutorów jej woli, J.A. Koniecpolski wszedł w posiadanie oryginału testamentu Anny, który - jeśli wierzyć ustaleniom I. Kotowej - pierwotnie znalazł się w rękach Michała Bartłomieja Tarły, proboszcza parafii Świętego Krzyża w Warszawie. Niewykluczone, że przejęcie oryginału testamentu przez J.A. Koniecpolskiego nastąpiło już po ugodzie w sprawie spadku po poetce, którą koniuszy koronny miał zawrzeć ze Zgromadzeniem Księży Misjonarzy ${ }^{31}$.

Podawany do druku akt ostatniej woli Anny ze Stanisławskich Zbąskiej jest oryginałem, który nie został jednak spisany ręką poetki. Bliższe przyjrzenie się pismu dokumentu wskazuje, że testament spisał ks. Stani-

29 J. Sondel, Stownik łacińsko-polski dla prawników i historyków, Kraków 1997, s. 162.

30 Por. J. Pielas, Podziały majattkowe szlachty koronnej w XVII wieku, Kielce 2013, s. 104.

31 I. Kotowa, op. cit., s. 277. 
sław Ostrowski (zm. 1700), kanonik sandomierski (1684-1700), proboszcz i oficjał radomski (1693-1700). Po jego zredagowaniu przez tegoż duchownego własnoręczny podpis pod nim złożyła A. Zbąska wraz z przyciśnięciem pieczęci sygnetowej z herbem Pilawa, odciśniętej w czarnym wosku (fot. 1). Fakt, że testament $\mathrm{z}$ ewidentnym rozmysłem przygotowano kilka lat przed śmiercią Anny, zadecydował o tym, że jest on uporządkowany $\mathrm{w}$ treści i nie nosi w sobie - jak to często bywało w przypadku testamentów sporządzanych pośpiesznie w obliczu choroby czy nadzwyczajnych wydarzeń $^{32}$ - obrazu uczuć czy rozterek testatorki, nie mówiąc już o szerszych rozważaniach natury filozoficznej, obecnych przecież w wielu miejscach w Transakcyi. Ze wzmianki na odwrocie ostatniej strony testamentu wynika, że został on oblatowany $\mathrm{w}$ aktach konsystorskich radomskich 14 lipca 1696 r. Niestety, ksiąg tych dziś już nie ma ${ }^{33}$.

W tym miejscu chciałbym podkreślić, że w najbliższym czasie przeprowadzone będą dodatkowe kwerendy archiwalne w poszukiwaniu materiałów źródłowych dotyczących życia i działalności Anny ze Stanisławskich Zbąskiej. W pierwszej kolejności zakres kwerend obejmie ostatnie lata jej życia i okres tuż po jej śmierci, co zapewne pozwoli w większym stopniu odtworzyć jej działalność u schyłku życia, a ponadto umożliwi dokładniej niż w niniejszym opracowaniu odpowiedzieć na pytanie o stopień i sposoby realizacji jej ostatniej woli przez wyznaczonych do tego egzekutorów. W dalszej perspektywie czasowej zgromadzone zostaną źródła odnoszące się do dziejów jej rodziny z linii ojcowskiej i macierzystej oraz małżonków poetki, a także materiały dokumentujące jej działalność prawno-majątkową i fundacyjną. W związku z powyższym wypada wyrazić nadzieję, że efektem tych starań będzie szczegółowa i odpowiadająca wymogom współczesnej nauki biografia Anny ze Stanisławskich Zbąskiej, pierwszej polskiej poetki.

Źródło zostało wydane stosownie do wskazań instrukcji wydawniczej dla źródeł nowożytnych ${ }^{34}$.

32 Testamenty szlachty krakowskiej, Wstęp, s. XIII.

${ }^{33}$ Jedyna zachowana do dziś księga oficjalatu radomskiego znajduje się w Archiwum Kapituły Kolegiackiej i Katedralnej w Sandomierzu i obejmuje lata 1531-1546. Zob. Inwentarz rękopisów Archiwum Kapituły Kolegiackiej i Katedralnej w Sandomierzu XIII-XX wieku, oprac. F. Kiryk, Sandomierz 2010, nr 833, s. 328.

${ }^{34}$ Instrukcja wydawnicza dla źródeł historycznych od XVI do połowy XIX wieku, red. K. Lepszy, Wrocław 1953. 


\section{TEKST ŹRÓDŁOWY}

\section{Testament Anny ze Stanisławskich Zbąskiej spisany w zamku w Maciejowicach w dniu 7 lipca 1696 r.}

Źródło: Oryginał. Archiwum Narodowe w Krakowie (oddział na Wawelu), Archiwum Podhoreckich IV/XXIX, dok. nr 3, nlb.

W imię Ojca i Syna i Ducha Ś[więtego]. Amen.

Wiedząc i pilno uważając, jako z jednej strony nieuchroniona kożdego człowieka śmiertelności czeka kondycja, a z drugi[ej] według słów i przestrogi przedwiecznej prawdy samego wcielonego Boga moment i godzina śmierci niepewny i w ten czas częstokroć bli[ż]szy i według opiniej i aparencyjej ludzki[ej] może się zdać być dalszym i odleglejszym, dlatego, zostając z łaski i miłosierdzia Boga mojego na umyśle i ciele zdrowa wcześnie jednak dla wszelakich przypadków, które na życie ludzkie niespodzianie przychodzić zwykły, użyczonej mi nieskończonej dobroci Boskiej jakiżkolwiek fortuny, będąc tak ojczystych jako i macierzystych moich ostatnią i jedyną dziedziczką i wolną sobie według prawa pospolitego do dyspozycyjej panią dóbr moich własnych, takową ostatnią czynię ordynacja, zostawując sobie jednak moc i władza, jeżeli by mi się tak na potym zdało, onę lubo we wszystkich, lubo w niektórych tylko punktach poprawić, odmienić, przydać, ująć lub też i kasować.

Naprzód tedy, dziękując Majestatowi Boskiemu za wszelakie łaski i dobrodziejstwa, mnie, lubo niegodnej grzesznicej, przez całe życie moje uczynionych, z tym się w oczach całego nieba i Kościoła Świętego oświadczam i protestuję, iż żyć i umierać w wierze ś[więtej] katolickiej rzymskiej chcę i pragnę, nadzieję moję w miłosierdziu Boskim, w męce i krwawych zasługach Pana i Zbawiciela jedynie pokładając, Przeczystej i Niepokalanej Boga Rodzicej Panny, tudzież i wszystkich świętych patronów moich o to gorąco upraszam, ażeby mi łaskę sczęśliwego z tego świata ześcia // i przy ostatnim życia mego zgonie prawdziwą i doskonałą za grzechy moje skruchę uprosić u Boga raczyli.

Ciało moje żeby według zwyczaju i obrządków Kościoła Świętego, bez żadnych jednak pomp i aparencyjej światowych, w habicie panien karmelitanek bosych w Lublinie w kościele Niepokalanego Poczęcia ${ }^{35}$ u tychże

35 Klasztor Karmelitanek Bosych przy kościele Niepokalanego Poczęcia Najświętszej Marii Panny w Lublinie, funkcjonujący w latach 1649-1819. Zob. m.in.: B.J. Wanat OCD, Zakon karmelitów bosych w Polsce. Klasztory karmelitów i karmelitanek bosych 1605-1975, Kraków 1979, s. 653-658; M. Borkowska OSB, Leksykon zakonnic polskich epoki przedrozbiorowej, t. 2, s. 359; eadem, Zakony żeńskie w Polsce w epoce nowożytnej, Lublin 2010, s. 338. 
przerzeczonych panien pochowane i pogrzebione było, ordynuję. Którym to pomienionym pannom karmelitankom lubelskim zaraz przy złożeniu ciała mojego 100 czerwonych zł z tych piniędzy, które się $\mathrm{w}$ gotowiźnie znajdować będa, na pogrzeb od JMPP egzekutorów niży opisanych wyliczone być maja za które przerzeczone panny zakonne według zwyczaju swojego pogrzeb odprawić powinny będą. Tymże pannom karmelitankom lubelskim klejnoty, jako to perły uriańskie, tak na szyję jako i na ręce, pierścieniów cokolwiek się znajdować będzie, bransolet diamentowy z trupią główką bransolet drugi z kamieniem i kameryzowany diamentami, czarkę złota, srebra fanslibru grzywien 50 i jedna i miednicę złocistą $\mathrm{z}$ nalewką $\mathrm{w}$ dziesiąciu tysięcy na dokończenie fabryki kościoła ordynuję, które aby zaraz oddane były, JMPP egzekutorów obliguję.

Na Msze Święte za duszę moję 10.000 naznaczam, które jako najprędzy z sumy gotowy po śmierci mojej będący w gotowiźnie, aby do rąk JM księdza Bartłomieja Tarła, proboscza Ś[więtego] Krzyża w Warszawie ${ }^{36}$ oddane były, który, kędy będzie rozumiał, wzwyż pomienioną sumę jako najprędzy rozda. 1.000 zł także // temuż JM do rąk oddać, aby ubogim także nieomieszkanie rozdał. 500 zaś złotych dla ubogich sierot w szpitalu warszawskim panien charitatis nazwanym ${ }^{37}$ temuż JM wyliczone $\mathrm{z}$ gotowizny wespół i z drugiemi dwiema sumami być mają.

Dóbr zaś moich takową czynię dyspozycją. Ponieważ nie podobało się dobroci Boskiej dać mi żadnego dziedzica i sukcesora, nie mając też tak dalece żadnego bliskiego z krewnych moich, oprócz JW JMP Jana Koniecpolskiego, koniuszego koronnego, brata mego ciotecznego z liniejej ojcowskiej ${ }^{38}$, któremu wielkie własnego domu fortuny i pańską substancją

${ }^{36}$ Michał Bartłomiej Tarło h. Topór (ur. 24 VIII 1656, zm. 20 IX 1715), syna Jana, wojewody sandomierskiego (1650-1667) i Anny z Czartoryskich, od 1679 r. członek Zgromadzenia Księży Misjonarzy, superior domu warszawskiego tegoż zgromadzenia, proboszcz parafii Świętego Krzyża w Warszawie i wizytator prowincji polskiej Zgromadzenia Księży Misjonarzy w latach 1685-1709, biskup poznański (1710-1715). Zob. m.in.: Katalogi biskupów poznańskich, oprac. J. Wiesiołowski, Poznań 2004, s. 62, 86, 167, 178, 203; A. Schletz CM, Ks. Biskup Michał Bartłomiej Tarło opiekun ubogich, „Nasza Przeszłość” 2011, 115-116, s. 23-32; P. Nitecki, Biskupi Kościoła w Polsce. Słownik biograficzny, Warszawa 1992, s. 207 oraz ostatnio: J. Dygdała, Tarło Michat Bartłomiej, w: PSB, t. 52, 2018 [w druku]. Dziękuję Redakcji Polskiego Słownika Biograficznego za udostępnienie mi biogramu M.B. Tarły przed jego publikacją.

37 Zgromadzenie Sióstr Miłosierdzia św. Wincentego á Paulo (szarytki) w Warszawie przy kościele pw. Św. Kazimierza, założone w 1652 r. przez królową Marię Ludwikę. Od 1684 r. szarytki warszawskie zarządzały szpitalem św. Marcina (zwanym później szpitalem Świętego Ducha). Zob. m.in.: A. Schletz, Historia Sióstr Miłosierdzia w Polsce, „Nasza Przeszłość” 1960, 12, s. 80-81; M. Borkowska OSB, Leksykon, t. 2, s. 113-114; eadem, Zakony żeńskie, s. 368.

38 Jan Aleksander Koniecpolski h. Pobóg (zm. 1719, zapewne 3 XII), syn Krzysztofa, wojewody bełskiego i Konstancji ze Stanisławskich, rotmistrz królewski, starosta ba- 
Bóg Najwy[ż]szy udzielił, a te dobra, które są w posesjej mojej, będąc moje własne macierzyste ${ }^{39}$, z której liniejej albo żadnych nie mam, abo daleko bardzo odległych mając krewnych, chcąc i pragnąc, żeby to wszystko co mam na chwałę tegoż samego Boga i Stwórcy mojego, który mi je udzielił, obrócieły, uniwersalnym dóbr moich wszystkich Dziedzicem, nie kogo inszego tylko Dawcę tychże dóbr, to jest Boga i Odkupiciela mego Chrystusa Jezusa czynię i deklaruję, chcąc i ordynując, ażeby wszystka ta, która się po śmierci mojej znaleźć będzie mogła, tak w ruchomych, jako i nieruchomych dobrach substancja, na chwałę Jego świętą w ten niży opisany sposób obrócona była.

Ponieważ tedy ta jest wola moja i nieodmienne postanowienie, ażeby dobra moje dziedziczne, to jest Macieiowice ze wszystkiemi przyległościami i należytościami w województwie sendomierskim a ziemi stężyckiej leżące ${ }^{40}$, także w województwie kaliskim będące Borkow, Skaryszowek i Chrostow ${ }^{41}$ przedane po śmierci mojej były i za nie sumy obrócone na // niży opisane legata, nie mogąc teraz dla interregnum i zamknięcia wszelakich akt publicznych należytego według prawa obmyślić sposobu do naznaczenia tego, który by tę wzwyż pomienioną substancją moję w ręce swoje objąć i onę prawnie przedać mógł, przybieram sobie tedy za opiekunów i egzekutorów tego testamentu i ostatniej woli mojej JO książęcia JMP Jana Stanisława Zbąskiego, biskupa warmińskiego ${ }^{42}$, JW JMP Karola Tarła,

liński od 1682 r., sieradzki (1691-1699), koniuszy wielki koronny (1692-1704), wojewoda bracławski (1704-1710), następnie sieradzki (1710-1719), brat cioteczny poetki. Zob. J.A. Gierowski, op. cit.; Urzędnicy centralni i nadworni Polski XIV-XVIII wieku. Spisy, oprac. K. Chłapowski et al., red. A. Gąsiorowski, Kórnik 1992 [dalej: UrzCentr.], s. 175; Urzędnicy województw łęczyckiego i sieradzkiego XVI-XVIII wieku. Spisy, oprac. E. Opaliński, H. Żerek-Kleszcz, red. A. Gąsiorowski, Kórnik 1993 [dalej: UrzSier.], s. 263.

39 Por. wyżej.

40 Majętność maciejowicka w województwie sandomierskim, powiecie stężyckim (ziemi stężyckiej) składała się z miasta Maciejowice, wsi Przewóz, Oronne, Polik, Oblin, Kochów, Uchacze, Strych, Godzisz, Komory, Podstolice, Domaszów (dziś Domaszew), Zakrzów, Samogoszcz, Bączki oraz folwarku Grocholka /Grochałka/. Dobra te odziedziczyła matka poetki, Krystyna z Szyszkowskich (por. przyp. 89), w wyniku podziału majątku ojcowskiego przeprowadzonego z siostra, Anną z Szyszkowskich Lanckorońska, we wrześniu 1650 r. Zob. Źródła i materiały do dziejów szlachty województwa sandomierskiego w XVIXVIII wieku, t. 3: Akty podziałów dóbr ziemskich szlachty sandomierskiej z XVII wieku, wstęp i oprac. J. Pielas, Kielce 2014, s. 65-69.

${ }^{41}$ Wsie Borków (dziś Borków Stary), Skaryszówek Mniejszy (dziś Skarszewek) i Chrostów (dziś Kolonia Skarszewek Chrusty) w województwie i powiecie kaliskim.

42 Jan Stanisław Zbąski h. Nałęcz (1639-21 V 1697), syn Stanisława i Heleny Konstancji z Przyjemskich, sekretarz królewski, kanonik (1665) i kustosz sandomierski (1666-1689), kanonik (1665) i archidiakon gnieźnieński (1671), kanonik warszawski, krakowski (1670), dziekan łowicki (1665), opat komendatoryjny sulejowski (1676), biskup przemyski (1677-1688), kanonik (1687) i biskup warmiński (1688-1697). Zob. J. Korytkowski, Prałaci i kanonicy kate- 
podkanclerzego koronnego ${ }^{43}$, JW JM księdza Stanisława ${ }^{a}$ Szembeka, sufragana i oficjała generalnego krako[w]skiego ${ }^{44}$, JW JMP Jana na Koniecpolu Koniecpolskiego, koniuszego koronnego ${ }^{45}$, JM księdza Bartłomieja Tarła, proboscza Ś[więtego] Krzyża warszawskiego ${ }^{46}$, JMP Franciszka Miaskowskiego, pisarza g[rodzkiego] konińskiego ${ }^{47}$, trzymając to po łasce JMM Państwa, że nie tylko z tej, którą mi we wszelakich okazjach świadczyć raczyli przyjaźniej, ale osobliwie dla chwały Boskiej pomnożenia z tej się pracy i usługi nie wymówią, dając JMM wszelaką moc i władzę do dyspozycyjej tej substancyjej i to upraszając, ażeby po śmierci mojej wszystkie dobra, tak ruchome jako i nieruchome po mnie pozostałe, w moc swoję i opiekę odebrawszy, jako najskuteczniejszy obmyśleli sposób, ażeby jako najprędzy sprzedane być mogły i sumy za nie odebrane niży opisanym sposobem dysponowane na legata były, nie dopusczając nikogo jakimkolwiek pretekstem do sukcesyjej po mnie się zabierającego, gdyż jako

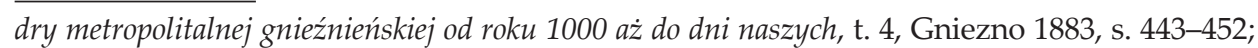
J. Wiśniewski, Katalog prałatów i kanoników sandomierskich od 1186 do 1926 r. tudzież sesje kapituły sandomierskiej od 1581 do 1866 r., Radom 1928, s. 323-324; L. Łętowski, Katalog biskupów, prałatów i kanoników krakowskich, t. 4, Kraków 1853, s. 303-307; J. Wieteska, Katalog prałatów i kanoników kapituly łowickiej od 1433 do 1970, Warszawa 1971, s. 75; P. Nitecki, op. cit., s. 235; B.S. Kumor, Dzieje diecezji krakowskiej do roku 1795, t. 1, Kraków 1998, s. 655.

${ }^{43}$ Karol Tarło h. Topór (zm. 1702 lub 1703), syn Piotra Aleksandra, wojewody lubelskiego (1630-1649) i Jadwigi z Lanckorońskich, wojewoda lubelski (1685-1689), podkanclerzy (1689-1702) i kanclerz wielki koronny (1702), starosta stężycki (1668-1686) i ponownie (1693-1695). Zob. W. Dworzaczek, Genealogia, cz. 2, Warszawa 1959 [dalej: Genealogia], tabl. 132; UrzCentr., s. 208; Urzędnicy województwa lubelskiego XVI-XVIII wieku. Spisy, oprac. W. Kłaczewski, W. Urban, red. A. Gąsiorowski, Kórnik 1991 [dalej: UrzLub.], s. 129; Urzędnicy województwa sandomierskiego XVI-XVIII wieku. Spisy, oprac. K. Chłapowski, A. Falniowska-Gradowska, red. A. Gąsiorowski, Kórnik 1993 [dalej: UrzSand.], s. 217.

a Imię poprawione z pierwotnie napisanego imienia: Władysława.

44 Stanisław Szembek h. własnego (1650-3 VIII 1721), syn Franciszka, kasztelana kamienieckiego (1688-1693) i Zofii z Pieniążków, kanonik przemyski (przed 1678), krakowski i archidiakon zawichojski (1678), proboszcz w Książu Wielkim (przed 1682), biskup dionizejski (1690), sufragan, wikariusz generalny i oficjał generalny krakowski (16901696), opat komendatoryjny mogilski (1690), biskup kujawski (1700-1705), opat komendatoryjny tyniecki (1705), arcybiskup gnieźnieński (1706-1721). M. Kosman, Między ołtarzem a tronem. Poczet prymasów Polski, Poznań 2000, s. 187-189; A.K. Link-Lenczowski, Szembek Stanisław, w: PSB, t. 48, Warszawa-Kraków 2012-2013, s. 115-122.

45 Por. przyp. 37.

46 Por. przyp. 35.

${ }^{47}$ Franciszek Miaskowski h. Bończa (zm. 1736), syn Feliksa i Marianny z Krzyckich, podstarości grodzki kaliski od 1680 r., pisarz grodzki koniński od 1686 r. do co najmniej 1696 r., miecznik wschowski (1726-1731), łowczy poznański (1731-1736). K. Niesiecki, Herbarz polski, wyd. J.N. Bobrowicz [dalej: Nies.], t. 6, Lipsk 1841, s. 379; Urzędnicy wielkopolscy XVI-XVIII wieku. Spisy, oprac. A. Bieniaszewski, red. A. Gąsiorowski, Wrocław 1987, s. 216 i nr 786; Testamenty szlacheckie z ksiag grodzkich wielkopolskich z lat 1681-1700, wyd. P. Klint, Wrocław 2015, s. 149, 412. 
według prawa pospolitego będąc sobie wolną dziedziczką i panią dóbr tych, onemiż wolno dysponować umyśliłam. Taksy jednak na te dobra nie zakładam, tylko takową, jaką mi sumę JMM różni dawali, lubom nie miała woli do przedaży, sami mnie z nią potykali, którzy nabyć chcieli // tychże dóbr, to jest za dobra maciejowskie ${ }^{48}$ trzykroć 100.000 currentis monetae ze wszystkiemi przyległościami, w wojewódz[t]wie zaś i powiecie kaliskim leżące dobra Borkow, Skaryszowek Mniejszy i Chrostow ze wszystkiemi przyległościami $^{49}$ zł 80.000 currentis monetae, za połowę wsi Odrany Woli cum attinentiis w ziemi warszawskiej leżącej ${ }^{50}$, kupnym sposobem nabytej i dekretami trybunalskiemi przysądzonej, złp 15.000 currentis monetae. Komputując tedy sumę wespół uczyni złp trzykroć dziewięćdziesiąt tysięcy i pięć ${ }^{51}$, oprócz inwentarzów, srebra, stada i inszych ruchomych rzeczy.

$\mathrm{Z}$ tych tedy sum tak naznaczam. Naprzód 100.000 na reparacyją biskupstwa wilińskiego i kościołów tamże spustoszałych ${ }^{52}$, które to piniądze do rąk JM księdza biskupa wileńskiego ${ }^{53}$ oddane być maja, trzymając to o sumnieniu JM WMP, że stosując się w tym do intencyjej mojej, pomienioną sumą jako najlepi[ej] dysponować będzie.

JMM księży misjonarzom na fundacją do Lublina ${ }^{54} 50.000$, a do tego tę część w dobrach rzecznioskich ${ }^{55}$ bez dekreta trybunalskie przysądzona, któ-

48 Por. przyp. 39.

49 Por. przyp. 40.

50 Wieś Odrana Wola (powstała najpewniej na miejscu dawnej wsi Matusowa Wola, dziś nosi nazwę Odrano-Wola) w województwie mazowieckim, ziemi warszawskiej, powiecie błońskim.

51 Jeśli przyjąć, że dobra maciejowickie wyceniane były na 300000 złp, to ewidentnie mamy w tym miejscu do czynienia z pomyłką w zapisie. Część zdania: „Komputując tedy sumę wespół uczyni złotych polskich trzykroć dziewięćdziesiąt i pięć” winno brzmieć: ,Komputując tedy sumę wespół uczyni złotych polskich trzysta [podkr. - J.P.] dziewięćdziesiąt tysięcy i pięć".

52 Biskupstwo rzymskokatolickie w Wilnie, stolicy Wielkiego Księstwa Litewskiego. O ówczesnych kościołach i kaplicach w Wilnie zob. m.in.: J. Kurczewski, Biskupstwo wileńskie, Wilno 1912, s. 153-175.

53 Konstanty Kazimierz Brzostowski h. Strzemieńczyk (1644-24 X 1722), kanonik wileński (1661), proboszcz trocki (1671), biskup smoleński (1685), następnie biskup wileński (1687-1722), opat komendatoryjny mogilski (1710). Zob. m.in.: W. Przyałgowski, Żywoty biskupów wileńskich, t. 3, Petersburg 1860, s. 74-122; J. Kurczewski, op. cit., s. 50-52; P. Nitecki, op. cit., s. 35 .

54 Klasztor księży misjonarzy w Lublinie, przy którym w latach 1701-1714 wybudowano i erygowano seminarium, zaś w latach 1719-1736 wybudowano kościół seminaryjny pw. Przemienienia Pańskiego. Zob. m.in. Księga pamiątkowa, s. 102-103; P. Krasny, Kościót Misjonarzy w Lublinie. Geneza form architektonicznych i problem autorstwa, „Kwartalnik Architektury i Urbanistyki" 1996, 41, s. 49-66. Por. http://teatrnn.pl/leksykon/artykuly/kosciolpw-przemienienia-panskiego-seminaryjny-w-lublinie/ [dostęp: 16 I 2018].

55 Od wsi Rzeczniów w województwie sandomierskim, powiecie radomskim, stanowiącej własność dziedziczną Stanisława Skarszewskiego, kasztelana wojnickiego (1667- 
ra po śmierci JW JejM Paniej kasztelanowej wojnickiej, pani dożywotniej ${ }^{56}$, mnie należeć powinna, na tęż fundacją lubelską tymże JMM przyłączam, z tą obligacja, ażeby ci JMM misjonarze sześciu kleryków w seminarium, według zwyczaju swojego, victum i stancją darmo prowidując, rok od roku zawsze na naukach i ćwiczeniu do stanu kapłańskiego trzymali. Te piniądze i prawa do tej części reczniowskiej należyte oddane być powinny do rąk Wielebnego JM ks[iędza] Bartłomieja Tarła, proboscza Ś[więtego] Krzyża w Warszawie i wizytatora tychże JMM ${ }^{\mathrm{b}}$ w Koronie Polskiej ${ }^{57}$.

// A że na dobrach moich maciejowskich, to jest na Godziszu ${ }^{58}$, zapisana suma ${ }^{c}$ JMP Kotoskiego niebosczyka ${ }^{59}$ przeze mnie 10.000 , to jest 5.000 na tymfy bez nad[d]atku, 5.000 zaś drugie currenti moneta do kolegium ojców w Warszawie ${ }^{\mathrm{d}}$ piarum $^{60}$, tedy, uwalniając pomienione dobra Go-

1685), która w 1696 r. znajdowała się w dożywotniej posesji wdowy po nim (por. przyp. 56). Nie udało się stwierdzić, na jakiej podstawie prawnej - w wyniku wspomnianego w testamencie procesu przez Trybunałem Koronnym - poetka uzyskała prawo do części dóbr rzeczniowskich, graniczących bezpośrednio z dobrami ziemskimi jej drugiego męża - Jana Zbigniewa Oleśnickiego (por. przyp. 87).

56 Katarzyna z Ginwiłł Piotrowskich h. własnego (1634-1710), córka Mikołaja, kuchmistrza litewskiego (1649-1657), zamężna primo voto za Hieronimem Wierzbowskim, wojewodą sieradzkim (1661-1665), secundo voto zaś za Stanisławem Skarszewskim h. Leszczyc (1602-4 IV 1685), dworzaninem królewskim, podstolim sandomierskim (1623-1648), kasztelanem małogoskim (1661-1667) i wojnickim (1667-1685), starostą stężyckim (1646/15471650), radomskim (1650-1654), samborskim (1656-1665 i 1673-1679), drohobyckim (1660), złotoryjskim, wasilkowskim i wielkorządcą krakowskim (1665-1675). M. Nagielski, Skarszewski Stanisław, w: PSB, t. 38, Warszawa-Kraków 1997-1998, s. 48-50; Urzędnicy województwa krakowskiego XVI-XVIII wieku. Spisy, oprac. S. Cynarski, A. Falniowska-Gradowska, red. A. Gąsiorowski, Kórnik 1990 [dalej: UrzKrak.], s. 133, 257; UrzSand., s. 211; UrzSier., s. 303; Urzędnicy centralni i dygnitarze Wielkiego Księstwa Litewskiego XIV-XVIII wieku. Spisy, oprac. H. Lulewicz, A. Rachuba, red. A. Gąsiorowski, Kórnik 1994, s. 229.

b W tym miejscu skreślony wyraz: zakonów.

57 Por. przyp. 35.

58 Por. przyp. 39.

c W tym miejscu skreślony wyraz: po.

${ }^{59}$ Najpewniej Adam Kotowski (zm. 21 X 1693 w Klementowicach w województwie lubelskim), sekretarz królewski, wielkorządca krakowski (1681-1683), stolnik wyszogrodzki (1676-1687), starosta bolimowski, krzeczowski, samborski, dzierżawca żup solnych krakowskich i ruskich, bankier, przez wiele lat (do 1683) właściciel klucza dęblińskiego z miastem Bobrowniki w powiecie stężyckim województwa sandomierskiego, a więc sąsiad poetki z powiatu. A. Keckowa, Kotowski Adam, w: PSB, t. 14, Wrocław-Warszawa-Kraków 1968-1969, s. 488-489; UrzKrak., s. 234.

d Określenie „w Warszawie” dopisano obok później, wykorzystując do tego także margines.

60 Kolegium pijarów (Zakonu Kleryków Regularnych Ubogich Matki Bożej Szkół Pobożnych) w Warszawie, ufundowane w 1642 r. przez Władysława IV Wazę. Zob. m.in. T. Chromecki, Krótki rys dziejów Zgromadzenia Szkót Pobożnych czyli OO. Pijarów, Kraków 1880, s. 52-53. 
dzisz od tej sumy, przenoszę ją na Odraną Wolą cum attinentiis w powiecie warszawskim leżącą ${ }^{61}$ oraz i przydając tymże ojcom piaru $[m]$ resztę sumy z tejże wsi mnie należytej, dając to na wolą pomienionym ojcom piarum lubo tą wyży za te dobra specyfikowaną kontentować się sumą, lubo też dobrami samemi. Za tę zaś sumę nad dług przypisaną daję to w moc JMPP egzekutorom, żeby proporcjalną obligacją przerzeczonym ojcom piaru $[\mathrm{m}]$ naznaczeli. Więc że na tychże jescze dobrach, to jest Godziszu, zostaje sumy do kościoła kurowskiego ${ }^{62}$ przeze mnie prebendarzowi tamecznemu zapisanej 4.000, także drugie 4.000 do Różańca promotorowi przy kościele maciejowskim ${ }^{63}$ zapisane, które to sumy wolno będzie JMPP egzekutorom lubo na dobra insze przy przedaży dóbr tych przenieść, lubo na tymże zostawić gruncie. Więc że znajduje [się] także zapis na 2.000 zł pannom karmelitankom lubelskim do Niepokalanego Poczęcia $^{64}$ na posag siestrze jednej, druga takoważ suma podobnym zapisem pannom karmelitankom warszawskim ${ }^{65}$ na tychże dobrach, które sumy lubo in fundo zostawać będa, lubo też przy przedaży majętności oneże wypłacą. Naznaczam także z przedaży dóbr tych także pannom karmelitankom lubelskim do Ś[więtego] Józefa ${ }^{66} 10.000$ na restauracją klasztora, drugie zaś 10.000 żeby na wyderkaf lokowana była, od której JejM Pannie Koniecpolski, siestrze mojej ${ }^{67}$, aby prowizja, w tymże klasztorze będącej,

61 Por. przyp. 49.

62 Kościół parafialny w Kurowie (dziś pw. Narodzenia Najświętszej Marii Panny i Św. Michała), mieście w województwie i powiecie lubelskim, stanowiącym własność dziedziczną Zbąskich, w tym trzeciego męża poetki - Jana Bogusława Zbąskiego h. Nałęcz (zm. w listopadzie 1683), chorążego (1664-1678) i podkomorzego lubelskiego (1678-1683). W 1690 r. poetka wystawiła w Kurowie murowany kościół w miejscu dawnego drewnianego i doprowadziła do jego konsekracji. Zob. m.in.: Rejestr poborowy województwa lubelskiego (powiat lubelski i urzędowski z r. 1626, ziemia łukowska z r. 1620), oprac. J. Kolasa, K. Schuster, red. S. Inglot, Wrocław 1957, s. 135; D. Rott, op. cit., s. 54; K. Targosz, Sawantki, s. 306; UrzLub., s. 133.

63 Kościół parafialny pw. Najświętszej Marii Panny w Maciejowicach, mieście w województwie sandomierskim, powiecie stężyckim, zbudowany przez dziada poetki - Piotra Szyszkowskiego, kasztelana wojnickiego (por. przyp. 89). Zob. m.in.: F. Kiryk, Urbanizacja Małopolski. Województwo sandomierskie XIII-XVI wiek, Kielce 1994, s. 72; M. Sokalski, Szyszkowski Piotr, w: PSB, t. 50, Warszawa-Kraków 2015, s. 417.

64 Por. przyp. 34.

65 Klasztor Karmelitanek Bosych przy kościele Świętego Ducha w Warszawie, funkcjonujący w latach 1649-1818, ufundowany przez kanclerza wielkiego koronnego Jerzego Ossolińskiego i jego żonę Izabelę z Daniłłowiczów. Zob. m.in.: B.J. Wanat OCD, op. cit., s. 659-662; M. Borkowska OSB, Leksykon, t. 2, s. 105; eadem, Zakony żeńskie, s. 339.

66 Klasztor Karmelitanek Bosych przy kościele Św. Józefa w Lublinie, funkcjonujący w latach 1624-1806. Zob. m.in.: B.J. Wanat OCD, op. cit., s. 629-636; M. Borkowska OSB, Leksykon t. 2, s. 351-352; eadem, Zakony żeńskie, s. 336-338.

67 Nieustalona z imienia Koniecpolska, karmelitanka bosa u Św. Józefa w Lublinie, córka Krzysztofa (zm. 1659), wojewody bełskiego (1641-1659) i Konstancji ze Stanisławskich, 
do śmiercie służeła, a po śmierci onejże // klasztorowi służyć ma. W Warszawie zaś tymże pannom karmelitankom ${ }^{68}$, oprócz tych 2.000 wyżej pomienionych, 3.000 na fabrykę kościelną leguję.

Do poznańskiego klasztoru tymże pannom karmelitankom ${ }^{69}$ naznaczam 10.000; jako będą rozumiały, niech dysponują onemiż. Oprócz zaś tego dana jest ode mnie asekuracja, na wielgopolskich dobrach ${ }^{70}$ zapisana, $^{2}$ na zł 1.000, a to na posag także pannie jednej, który to 1.000 jest u JMP pisarza koniń[skieg]o ${ }^{71}$ lokowany.

Przyobiecałam także była pannom karmelitankom bosym do Przemyśla ${ }^{72} 10.000$ na fundacja, te tedy 10.000 oddać do rąk ojca prowincjała, za wiadomością całego definitorium prowincjalskiego; jeżeli by miało przyść do tej fundacyjej, to te piniądze na nię łożyć, in quantum by nie przyszło, to na co potrzebniejszego będą rozumieli, wolno im będzie obrócić.

Na fundowanie szpitala w Warszawie przy kościele Ś[więtego] Krzyża JMM księży misjonarzów na Przedmieściu Krako[w]skim leżących ${ }^{73}$, a to dla ubogich chorych, osobliwie pomienionej parafiej, naznaczam 50.000, która to suma do rąk JM ks[iędza] proboscza pomienionego kościoła ${ }^{74}$ oddana być ma, z tą obligacją ażeby JMM księża misjonarze 20.000 na fabrykę wzwyż mianowanego szpitala obrócieli, 30 zaś tysięcy albo na dobrach jakich niezawiedzionych lokowali, albo za nie co pożytkującego kupieli

córki Adama Stanisławskiego, kasztelana halickiego (1649-1650), rodzonej siostry ojca poetki (por. przyp. 77), a więc jej siostra cioteczna. Krzysztof Koniecpolski miał kilka córek, przy czym wszystkie były zakonnicami. Dotychczas nie było wiadomo, do którego klasztoru Karmelitanek lubelskich wstąpiła wspomniana Koniecpolska. Nies., t. 5, s. 201; S. Uruski, Rodzina. Herbarz szlachty polskiej, t. 7, wyd. A.A. Kosiński, A. Włodarski, Warszawa 1910, s. 174; UrzCentr., s. 175; A. Kersten, Krzysztof Koniecpolski, w: PSB, t. 13, Warszawa-Kraków 1967-1968, s. 521-522; Genealogia, tabl. 138; M. Borkowska OSB, Leksykon t. 2, s. 359.

e W tym miejscu ponowione i podkreślone słowo: prowizja.

68 Por. przyp. 64.

${ }^{69}$ Klasztor Karmelitanek Bosych przy kościele Najświętszego Imienia Maryi w Poznaniu, funkcjonujący w latach 1665-1823. Zob. m.in.: B.J. Wanat OCD, op. cit., s. 663-668; M. Borkowska OSB, Leksykon zakonnic polskich epoki przedrozbiorowej, t. 1: Polska Zachodnia i Pótnocna, Warszawa 2004, s. 124.

70 Por. przyp. 40.

71 Por. przyp. 46.

${ }^{72}$ Do fundacji klasztoru Karmelitanek Bosych w Przemyślu wówczas nie doszło. Klasztor Matki Bożej z Góry Karmelu w Przemyślu powstał dopiero w 1884 r. Zob. m.in.: B.J. Wanat OCD, op. cit., s. 692-695.

73 Dom warszawski Zgromadzenia Księży Misjonarzy przy kościele pw. Świętego Krzyża w Warszawie na Krakowskim Przedmieściu, funkcjonujący w latach 1653-1864. Od 1653 r. księża misjonarze sprawowali również patronat, należący wcześniej do miasta, nad szpitalem dla 6 ubogich. Zob. m.in.: Księga pamiątkowa, s. 69-77; E. Kowalczykowa, Kościót Św. Krzyża, Warszawa 1975.

74 Por. przyp. 35. 
albo wybudowali, skąd by prowizja na dwie siostry charitatis, które przy szpitalu dla przysługi chorych osadzone być mają i na ubogich chorych iść mogą chcąc i deklarując, ażeby ten szpital pod dyrekcją i rządem tychże JMM księży misjonarzów na zawsze zostawał.

$\mathrm{Na}$ fundacją także przerzeczonych sióstr charitatis nazwanych w Lublinie $^{75}$, ażeby ubogim chorym usługowały, odkazuję dworek mój w Lublinie będący, przydając do tego 20.000 sumy, która aby na prowizją lokowana była ${ }^{76}$.

Do ojców dominikanów lwowskich ${ }^{77}$, gdzie ociec mój leży ${ }^{78}$, naznaczam 10.000, z tą obligacja żeby za duszę jego // i inszych przodków moich co tydzień dwie msze odprawowały się i raz w rok aniwersarz.

Do panien benedyktynek radomskich ${ }^{79}$, upatrując sczupłość fundacyjej tamtecznej, naznaczam 10.000, ażeby oblig jaki wzięły na się.

75 Dom lubelski Zgromadzenia Sióstr Miłosierdzia św. Wincentego à Paulo (szarytek) w Lublinie. Za datę jego powstania przyjmuje się dopiero rok 1730. Zob. m.in.: Z. Molenda, Jubileuszowe dziękczynienie szarytek w Lublinie, „Niedziela” 2002, 10, http://www.niedziela. pl/artykul/68577/nd/Jubileuszowe-dziekczynienie-Szarytek-w [dostęp: 17 I 2018]; M. Borkowska OSB, Zakony żeńskie, s. 364.

${ }_{76}$ Literatura przedmiotu potwierdza, że zapis poetki był jedną z podstaw fundacji domu lubelskiego szarytek, przy czym odnotowuje zapis dworku w Lublinie i $9000 \mathrm{zł}$. Zob.: Zgromadzenie Sióstr Miłosierdzia św. Wincentego á Paulo w Polsce (1652-2002), t. 2, red. A. Dzierżak, S. Motyka, W. Bomba, J. Dukała, Kraków 2002, s. 230; A. Szylar, Działalność wychowawczo-edukacyjna żeńskich zgromadzeń zakonnych w Małopolsce w okresie potrydenckim do 1815 r., Kraków 2012, s. 98.

77 Klasztor Dominikanów przy kościele pw. Bożego Ciała we Lwowie, funkcjonujący od XIII w. do 1945 r. Zob. m.in.: S. Barącz, Rys dziejów zakonu kaznodziejskiego w Polsce, t. 2, Lwów 1861, s. 443-459 i ostatnio: J.A. Spież OP, „Figle i niedole” poddanych dominikańskiego klasztoru pw. Bożego Ciała we Lwowie z majatku w Dawidowie w XVIII w., w: Klasztor w gospodarce średniowiecznej i nowożytnej, red. M. Derwich, Wrocław 2013, s. 461-480.

78 Michał Stanisławski h. Pilawa (zm. 1668), syn Adama, kasztelana halickiego (1649_ 1650), chorąży halicki (1650-1663), kasztelan sądecki (1663-1665), wojewoda kijowski (1665-1668). M. Nagielski, Stanisławski Michat, s. 120-124; UrzKrak., s. 259 (tu błędnie, podobnie jak w biogramie w PSB, przypisany Stanisławskiemu herb Gryf - wszelkie wątpliwości $\mathrm{w}$ tym względzie rozwiewa pieczęć z herbem Pilawa przyciśnięta przez poetkę w testamencie); Urzędnicy województw kijowskiego i czernihowskiego XV-XVIII wieku. Spisy, oprac. E. Janas, W. Kłaczewski, Kórnik 2002, s. 323; UrzRus., s. 391. Dotychczas miejsce spoczynku ojca poetki we Lwowie nie było znane. W swym dziele Anna ze Stanisławskich Zbąska podała, iż miał miejsce „We Lwowie pogrzeb [...]” (Transakcya, s. 48). Autor biogramu Stanisławskiego w PSB zaznaczył jedynie, że „pogrzeb Stanisławskiego odbył się w lutym 1669, zapewne we Lwowie". M. Nagielski, Stanisławski Michat, s. 122. Warto w tym miejscu dodać, że poetka w swej autobiografii jasno określiła również miejsce śmierci ojca, który zmarł w Podkamieniu w ziemi lwowskiej (Transakcya, s. 37).

79 Klasztor Benedyktynek przy kościele pw. Trójcy Świętej w Radomiu, funkcjonujący w latach 1627-1810. Zob. m.in.: M. Borkowska OSB, Klasztor benedyktynek radomskich $i$ jego rola w życiu religijnym $i$ kulturalnym Radomia i ziemi radomskiej, w: Radom i region radomski 
Do panien Kletek w Krakowie na Stradomiu ${ }^{80}$ naznaczam 10.000, ażeby je gdzie lokowały na prowizją sobie, za co JMPP egzekutorowie obligacja, jako będą rozumieli, naznaczą.

Do Kalisza ${ }^{f}$ pannom franciszkankom ${ }^{81} 4.000$ na klasztor, także pannom bernardynkom tamtecznym ${ }^{82} 3.000$ zł na potrzeby ich zakonne, za które oblig JMPP egzekutorowie naznaczyć powinni.

Do kościoła borkowskiego ${ }^{83}$ naznaczam 6.000 , to jest na zniesienie wyderkafu 1.500 przez nieboszkę JejM Panią Żuchowską, babkę moję, zapisanego ${ }^{84}, 1.500$ zaś na wybudowanie kościoła, 3.000 zaś na wikarego i odprawowanie różańca przy tamtecznym kościele.

$w$ dobie szlacheckiej Rzeczypospolitej, t. 2: Historia społeczno-religijna okresu wczesnonowożytnego, red. Z. Guldon, S. Zieliński, Radom 1996, s. 67-82; eadem, Leksykon, t. 2, s. 368; eadem, Zakony żeńskie, s. 299.

${ }^{80}$ Klasztor Bernardynek z kaplicą pw. Św. Kolety (zakonnice zwano koletkami) na Stradomiu w Krakowie, funkcjonujący w latach ok. 1593-1788. Zob. m.in.: Katalog zabytków sztuki w Polsce, t. 4: Miasto Kraków, cz. 5: Kazimierz i Stradom. Kościoty i klasztory, red. I. Rejduch-Samkowa, J. Samek, Warszawa 1978, s. 97-100; Testamenty szlachty krakowskiej, s. 116; A. Szylar, op. cit., s. 60; M. Borkowska OSB, Zakony żeńskie, s. 309.

f W tym miejscu zamazany wyraz: tak.

${ }^{81}$ Klasztor Franciszkanek (Franciszkanek-Klarysek) przy kościele pw. Matki Boskiej Ofiarowania w Kaliszu, funkcjonujący w latach ok. 1618-1805. Zob. m.in.: J. Raciborski, Monografja Kalisza, cz. 1, Kalisz 1912, s. 43; M. Borkowska OSB, Leksykon, t. 1, s. 47.

${ }^{82}$ Klasztor Bernardynek przy kościele pw. Niepokalanego Poczęcia Najświętszej Marii Panny w Kaliszu, funkcjonujący od drugiej połowy XV w. do 1804 r. Zob. m.in.: S. Szczeblewski, Klasztor bernardynek kaliskich na podstawie tzw. kaliskiego kopiarza, „Studia Włocławskie” 2016, 18, s. 451-464; M. Borkowska OSB, Zakony żeńskie, s. 307; eadem, Leksykon, t. 1, s. 38.

${ }^{83}$ Kościół parafialny pw. Św. Andrzeja Apostoła we wsi Borków, dziedzicznej w rodzinie Szyszkowskich (por. przyp. 40). Marcin Szyszkowski (1554-1630), biskup krakowski (1616-1630) w swym testamencie zobowiązał Mikołaja Szyszkowskiego (ok. 1589-1643), biskupa warmińskiego (1633-1643) i swego bratanka, do wystawienia w Borkowie murowanej świątyni, z czego ten się jednak nie wywiązał. Dopiero w $1710 \mathrm{r}$. Michał Bartłomiej Tarło, biskup poznański (por. przyp. 35), wzniósł istniejący do dziś kościół, niewątpliwie wykorzystując do tego celu sumy zapisane przez poetkę w publikowanym testamencie. Zob. m.in.: J. Łaski, Liber beneficiorum archidioecesis Gnesnensis, t. 2, ed. J. Łukowski, Gnesnae 1881, s. 84; A. Biedrzycka, Szyszkowski Mikołaj, w: PSB, t. 50, Warszawa-Kraków 2015, s. 407.

g W tym miejscu skreślona część wyrazu: pułt [zapewne: półtora - J.P.].

${ }^{84}$ Nie podejmując się w tym miejscu szczegółowej prezentacji genealogii poetki, wypada zaznaczyć, że żadna z jej babek sensu stricto nie wywodziła się z Żuchowskich, ani też nie nosiła tego nazwiska. Babką z linii ojcowskiej była bowiem Agnieszka z Krężelewskich, żona Adama Stanisławskiego, kasztelana halickiego, zaś babką z linii macierzystej Zofia z Zebrzydowskich, druga żona Piotra Szyszkowskiego, kasztelana wojnickiego (por. przyp. 89). Prababkami z linii macierzystej (z Borkowem byli bowiem związani Szyszkowscy) była Anna z Wiesiołowskich, żona Jerzego Szyszkowskiego oraz Barbara z Lubomirskich, żona Jana Zebrzydowskiego, miecznika koronnego (1620-1641). Zob. m.in.: Archiwum Narodowe w Krakowie (Oddział na Wawelu), Archiwum Podhoreckich IV, 
Do kościoła maciejowskiego ${ }^{85} 3.000$ zł odkazuję, za które obliga jedna w tydzień przez obrazem Naświętszej Panny i aniwersarz za duszę moję raz w rok, oprócz tej mszej, którą ks[iądz] prebendarz z fundacyjej swojej odprawować powinien.

Na szpital przy kościółku w Macieiowicach Naświętszej Panny Zwiastowania ${ }^{86}$, aby wybudowany był na siedmi ubogich, naznaczam $5.000^{\mathrm{h}}$, to jest ${ }^{\mathrm{h}}$ na budynek zł 500, a półpięta tysiąca na prowizją. $Z$ osobna na księdza, który tam będzie odprawiał mszą świętą raz w tydzieńi przydaję 1.000 zł, od którego corocznia prowizja aby go dochodzieła. Te tedy sumy albo in fundo zostawić, albo też gdzie indzi[ej] na pewnym lokować miejscu.

Do kościoła tarłowskiego ${ }^{87}$ naznaczam także 3.000 zł, aby za duszę mego niebosczyka Oleśnickiego, męża ${ }^{88}$, msza święta raz w tydzień i aniwersarz raz w rok odprawować się będzie powinien.

sygn. Podh. XII 21/6; A. Boniecki, Herbarz polski [dalej: Bon.], t. 12, Warszawa 1908, s. 283; Genealogia, tabl. 134; UrzCentr., s. 21; M. Sokalski, op. cit., s. 416-417. Natomiast wśród bliskich krewnych dziada poetki - Piotra Szyszkowskiego, kasztelana wojnickiego (por. przyp. 89), widzimy Zofię z Szyszkowskich Rzuchowską, wzmiankowaną w źródłach w latach 1658-1666 wdowę po Eustachym Dunin-Rzuchowskim h. Łabędź (zm. przed 1658), matkę Aleksandra-Mariana, rotmistrza królewskiego. W 1665 r. jako dziedziczka wsi Borków (Borkowo) (por. przyp. 40) zapisała ona na tej wsi miejscowemu kościołowi (por. przyp. 82) czynsz wyderkafowy od sumy $1500 \mathrm{zł} \mathrm{w} \mathrm{grodzie} \mathrm{konińskim.} \mathrm{Biblioteka}$ Polskiej Akademii Nauk w Kórniku, Teki Dworzaczka (online). Wobec znacznego rozrodzenia Szyszkowskich w XVI w. i na początku XVII w. precyzyjne określenie więzów genealogicznych łączących poetkę ze wspomnianą Zofią z Szyszkowskich Rzuchowską wymaga dalszych, pogłębionych badań genealogicznych.

85 Por. przyp. 62.

86 Kościółek pw. Zwiastowania Najświętszej Marii Panny w Maciejowicach (por. przyp. 39). Nie odnaleziono dotąd wiarygodnej informacji źródłowej, że fundacja szpitala doszła do skutku. Por. m.in. Z. Guldon, W. Kowalski, Szpitale w województwie sandomierskim w drugiej połowie XVII wieku, „Nasza Przeszłość” 1995, 84, s. 81-134.

h Wyrazy nadpisane.

i W tym miejscu skreślone wyrazy: odprawować będzie.

87 Kościół parafialny pw. Świętej Trójcy w Tarłowie, mieście w województwie i powiecie sandomierskim, wzniesiony przez Zbigniewa Oleśnickiego (1603-1662), kasztelana wiślickiego (1650-1662), stryja drugiego męża poetki - Jana Zbigniewa Oleśnickiego, podkomorzyca sandomierskiego (por. przyp. 88). Zob. J. Pielas, Oleśniccy, s. 400-402 i tabl. IV.

${ }^{88}$ Jan Zbigniew Oleśnicki h. Dębno (zm. po 13 IX 1674 przed 9 II 1675, pochowany w kościele w Tarłowie - por. przyp. 87), syn Jana (1605-1675), podkomorzego sandomierskiego (1637-1675) i Zofii z Kurdwanowskich, primo voto żonaty z Katarzyną z Lanckorońskich (zm. 1668/1669), secundo voto od stycznia lub lutego 1670 r. z poetką. Zob. J. Pielas, Oleśniccy, szczególnie s. 350-355, 380-384 oraz tabl. IV. 
Do kościoła wrzesczowskiego ${ }^{89}$ przez matkę moję ${ }^{90}$ zapisana także na dobrach suma 1.000 zł, do której i ja przyłączam 500 zł, aby z tych dóbr zniesione były i do rąk oddać tamtecznemu pasterzowi, żeby ją na inszym miejscu należycie lokował.

// Pannom bernardynkom do Brześcia Litewskiego ${ }^{91}$, uważając ich sczupłość fundacyjej, leguję 3.000 na potrzeby ich klasztorne.

Na blachę do kościoła warszawskiego na pokrycie kaplicy u JMM Ojców misjonarzów ${ }^{92} 10.000$ leguję.

Do rąk ojca Franciszka piarum scholarum na dyspozycją jego leguję 5.000, a uchowaj Boże śmierci na niego, tedy w Krakowie do ojców piaru$[\mathrm{m}]$ scholarum $^{93}$, aby oddane były na klasztorne ich potrzeby.

JMP koniuszemu koronnemu, bratu memu ${ }^{\mathrm{j}, 94}$, daję $\mathrm{z}$ afektu mego siestrzeńskiego na potrzeby JM 20.000, JMP pisarzowi konińskiemu ${ }^{95} 6.000 \mathrm{zl}$, 6.000 zaś na JMM: JMP Szołowskiego, Siewierskiego i Bogdańskiego ${ }^{96}$, in-

89 Kościół parafialny we wsi Wrzeszczów w województwie sandomierskim, powiecie radomskim, zniszczony przez żołnierzy rosyjskich w 1707 r. J. Wiśniewski, Dekanat radomski, Radom 1911, s. 382.

90 Krystyna z Szyszkowskich (zm. ok. 1654), córka Piotra, kasztelana wojnickiego (1638-1645), primo voto żona Jana Stefana Niszczyckiego, chorążego bełskiego, następnie Michała Stanisławskiego, matka poetki. M. Nagielski, Stanisławski Michał, s. 123 (tu błędne imię żony); I. Kotowa, op. cit., s. 269-270.

91 Klasztor Bernardynek przy kościele pw. Niepokalanego Poczęcia Najświętszej Marii Panny w Brześciu Litewskim, funkcjonujący w latach 1624-1831. Zob. m.in. M. Borkowska OSB, Zakony żeńskie, s. 305.

92 Por. D. Rott, op. cit., s. 54, gdzie podano, że dzięki zapisowi poetki w 1700 r. pokryto miedzią kaplicę Matki Boskiej przy kościele Świętego Krzyża w Warszawie.

93 Kolegium pijarów (Zakonu Kleryków Regularnych Ubogich Matki Bożej Szkół Pobożnych) w Krakowie, powstałe na mocy zezwolenia biskupa krakowskiego Andrzeja Trzebickiego z 1660 r. najpierw na Kazimierzu, a następnie od 1679 r. funkcjonujące w centrum Krakowa na ul. Św. Jana z kościołem Przemienienia Pańskiego. Zob. m.in.: T. Chromecki, op. cit., s. 123-141; Katalog zabytków sztuki w Polsce, t. 4: Miasto Kraków, cz. 3: Kościoty i klasztory śródmieścia 2, red. A. Bochnak, J. Samek, Warszawa 1978, s. 95-108.

j Wyraz nadpisany.

94 Por. przyp. 37.

95 Por. przyp. 46.

96 Zapisy poetki na rzecz wymienionych były następstwem skomplikowanych (trudnych do ustalenia na obecnym etapie badań nad genealogią Szyszkowskich w XVI i XVII w.) rozliczeń związanych z dziedziczeniem w obrębie tejże rodziny. Z ustaleń H. Żerek-Kleszcz wynika, że Jan Szyszkowski (którego nazywa wojskim kaliskim, choć spisy urzędników o nim milczą), bratanek Mikołaja (zm. 1650 lub 1651), podkomorzego wieluńskiego (1630 1650), miał 4 siostry. Elżbieta, wzmiankowana w Tekach Dworzaczka w latach 1669-1677, po śmierci pierwszego męża - Stanisława Żuchowskiego (zm. przed 1669) wyszła za mąż za Marcina Czartkowskiego. Katarzyna przed 1638 r. poślubiła Piotra Bogdańskiego h. Prus III (zm. przed 1638), z którym doczekała się syna Piotra, wzmiankowanego w latach 1666-1673, któremu to najpewniej poetka zapisała część z sumy 6000 zł (Katarzyna poślubiła następnie Adama Lutomirskiego). Marianna przed 1641 r. wyszła za mąż za Jana Wszołowskiego (Szo- 
kludując dług 1.000 zł, który sobie pretenduje JMP Bogdański na Borkowie $^{97}$, aby post fata moje JMM wyliczone były.

JMP Kołudzkiemu Andrzejowi ${ }^{\mathrm{k}, 98}$ długu pozostałego z dekretu trybunalskiego przy mnie zł 1.000 po niebosczyku JM ${ }^{99}$, którego JM dla uporu swego dawno od[e]brać nie chciał, wyliczyć za kwitem należytym obliguję JMPP egzekutorów.

Zostawuje jescze na zniesienie długów borkoskich przez testament babki mojej ${ }^{100}$ legowanych i jeżeli się jescze jakie pokaża, zł 1.200, to jest ojcom do Ś[więtego] Mikołaja w Kaliszu ${ }^{101}$ zł 300, ojcom bernardynom do Kalisza $^{102}$ zł 700, do fary ${ }^{103}$ wyderkafu zł 200.

Słudze mojej, Paniej Zofiej Naganowskiej, [do] przeze mnie zapisany sumy półtora tysiąca z osobna przyłączam zł 500, którą to sumę z gotowizny wypłacić, proszę JMPP opiekunów i obliguję. Paniej Berezynej, który puściełam Grochałkę folwark i z poddanemi opisanemi w Poliku ${ }^{104}$ do śmierci onejże, naznaczam z dóbr wyliczyć zł 1.000. Białogłowom moim, które na usłudze mojej zostaja jeżeli by się zostało co zasłużonego, lubo im corocznie płacę, // tedy wprzód zasługi wypłaciwszy z gotowiznej za przedażą substancyjej mojej, naznaczam: Humieckiej, pokojowej mojej, zł 500, Sosposkiej zł 200, Pannie Priuszównie na jej potrzebę zł 300, P[annie?] Wielskiej zł 100, Gleyzerównie zł 300, Białkoskiej zł 200, szwac[z] ce Anusiec[z]ce zł 100, na małe dwie dziewczęta zł 100, kucharce zł 100,

łowskiego), zapewne h. Wczele, z którym miała synów: Stanisława, Marcina oraz Krzysztofa i zapewne to jeden $\mathrm{z}$ nich był beneficjentem zapisu poetki. Czwarta z sióstr, Zofia, potwierdzona jest w 1631 r. jako żona Stanisława Siewierskiego, o których męskim potomstwie nie udało się odnaleźć pewnych źródłowych informacji. Biblioteka Polskiej Akademii Nauk w Kórniku, Teki Dworzaczka (online); Bon., t. 1, Warszawa 1889, s. 330; Nies., t. 8, s. 372.

97 Por. przyp. 40.

k Imię nadpisane.

98 Najpewniej chodzi o syna famulusa drugiego męża poetki, Jana Zbigniewa Oleśnickiego. W latach sześćdziesiątych i siedemdziesiątych XVII w. w źródłach poświadczony jest bowiem Stanisław Kołudzki, szlachcic-famulus mieszkający w dobrach Oleśnickich. Zob. J. Pielas, Oleśniccy, s. 343, 359, 409.

99 Por. przyp. 87.

${ }^{100}$ Por. przyp. 83.

${ }^{101}$ Kościół farny pw. św. Mikołaja w Kaliszu, wzniesiony w XIII w., od 1441 r. kolegiata zakonna Zgromadzenia Kanoników Laterańskich, którzy to zakonnicy funkcjonowali w tym miejscu do 1810 r. Zob. m.in.: J. Raciborski, op. cit., s. 14; Dzieje Kalisza, red. W. Rusiński, Poznań 1977, s. 74-75, 248-249.

102 Klasztor Bernardynów przy kościele pw. św. Anny i św. Bernardyna ze Sieny w Kaliszu, wybudowany poza murami miasta na Przedmieściu Toruńskim, funkcjonujący w latach 1465-1864. Zob. m.in.: H.E. Wyczawski OFM, Klasztory bernardyńskie w Polsce w jej granicach historycznych, Kalwaria Zebrzydowska 1985, s. 107-113.

${ }^{103}$ Por. przyp. 100.

${ }^{104}$ Por. przyp. 39. 
praczkom dwiema po zł 50. Z osobna Panom Chodakowskim, małżonkom $^{105}$, naznaczam zł 1.000 .

Sługom zaś moim pozostałym, jeżeli by się z regestrów co pokazało zatrzymanych zasług, aby według należytości z gotowizny zaraz zapłacono. I nadto naznaczam zł 300, osobliwie między drobniejszą czeladź, aby kożdego ukontentować według proporcjej, tych, którzy dawni[ej] służą. Bieleckiemu zatrzymanych zasług zostaje przy mnie zł 100, po które kazałam mu dawno przyjechać; że tedy przez tak dawny czas nie był i nie upominał się, tedy aby nal msze za niego dane były, ordynuję.

Na kościół, który zaczynać myśla, pannom wizytkom warszawskim ${ }^{106}$ ordynuję zł 3.000 .

Z przedanych zaś inwentarzów, stada, srebra i inszych ruchomości upraszam JMPP egzekutorów, aby między różne kościoły, klasztory, które będą baczyli być potrzebniejsze, chcieli ordynować, a osobliwie JMM księży kapucynom do Krakowa ${ }^{107}$ na zaczynającą się fundacją 3.000 zł.

Ojcom reformatom kazimierskim ${ }^{108}$ zł 1.000, ojcom franciszkanom w Stężycej ${ }^{109}$ zł 1.000, ojcom bernardynom do Góry ${ }^{110}$ zł 500 na obligi.

Co się zaś pokaże więcy nad moję dyspozycją to wszystko daję w moc JMPP egzekutorom, gdyż jeżeli by i taksa dóbr większa // się znajdować

${ }^{105}$ Być może chodzi o Jana Chodakowskiego (i jego żonę), który jesienią 1667 r. wraz z Janem Zbigniewem Oleśnickim (por. przyp. 87) oraz we wrześniu 1674 r. posłował od szlachty sandomierskiej odpowiednio do Michała Korybuta i Jana III Sobieskiego. J. Pielas, Oleśniccy, s. 375; L.A. Wierzbicki, Poselstwa od szlachty województwa sandomierskiego do Michała Korybuta i Jana III (1670-1693), w: Z życia politycznego szlachty i ziemiaństwa między Wisła a Pilica w XVIXX wieku. Studia, red. J. Gapys, M. Nowak, J. Pielas, Kielce 2017, s. 80, 88.

1 W tym miejscu skreślona część wyrazu: kościo [zapewne: kościoły - J.P.].

${ }^{106}$ Klasztor Wizytek przy kościele pw. Nawiedzenia NMP w Warszawie, założony w 1654 r. przez królową Ludwikę Marię. Zob. m.in.: M. Borkowska OSB, Leksykon, t. 2, s. 147-148; eadem, Zakony żeńskie, s. 372.

${ }^{107}$ Zgromadzenie Kapucynów przy kościele pw. Najświętszej Marii Panny w Krakowie, funkcjonujące od 1695 r. Zob. m.in.: J. Marecki, Kościót i klasztor kapucynów w Krakowie, Kraków 1995.

${ }^{108}$ Klasztor Franciszkanów-Reformatów przy kościele pw. Św. Kazimierza w Krakowie, ufundowany w latach 1666-1672 przez Stanisława Warszyckiego, kasztelana krakowskiego (1651-1681), ojca pierwszego męża poetki - Kazimierza Warszyckiego, kasztelanica krakowskiego. Zob. m.in.: M. Wilczyński, Klasztor świętego Kazimierza oo. reformatów w Krakowie, Kraków 1893; Katalog zabytków sztuki w Polsce, t. 4: Miasto Kraków, cz. 3, s. 1-16.

${ }^{109}$ Klasztor Franciszkanów w Stężycy, powstały w 1591 r., erygowany ponownie w 1633 r. przez kanclerza Jerzego Ossolińskiego, zniszczony w pożarze w 1790 r. Zob. m.in.: Stownik Geograficzny Królestwa Polskiego i innych krajów słowiańskich [dalej: SGKP], t. 11, red. B. Chlebowski, Warszawa 1890, s. 340.

${ }^{110}$ Klasztor Bernardynów w Górze Kalwarii (Górze) koło Warszawy przy kościele pw. Ofiarowania Najświętszej Marii Panny, funkcjonujący w latach 1670-1873. Zob. m.in.: H.E. Wyczawski, op. cit., s. 70-74. 
miała, na samo sumnienie i ro[z]sądek spusczam to JMM. Jeżeli by też zaś, strzeż Boże, dla przypadku i ruiny jakiej dobra te pod mniejszą cenę podpadać miały, daję to w moc i jurysdykcją JMM, żeby tym jako najlepi[ej] dysponowali.

O to tedy JMM jako najbardzi[ej] upraszam i obowięzuję sumnieniem, ażeby ${ }^{\dagger}$ według ostatniej a wyraźnej woli mojej te dobra za gotowe piniądze spieniężywszy, wyży opisaną dyspozycją moję zachować raczyli i dotąd tej substancyjej z rąk swoich nie wypusczali, póki realnej nie wybiorą sumy.

A że jescze i ojca mego ${ }^{111}$ substancyjej, która w nieprzyjacielskich zostaje rękach na Podolu ${ }^{112}$, dostatecznej nie mogłam czynić dyspozycyjej, tedy, jeżeli za łaską Boską te kraje do nas by się przywrócić miały, upraszam tychże JMPP egzekutorów, aby tąż moca, którą i do tych dóbr należeć będą i o tamte dobra pytać się chcieli i do nich interesować, które sprzedawszy jako najlepi[ej], będzie mogło być, aby połowę za te dobra sumy wzięty, według intencyjej ojca mego, na szpital żołnierski w Kamieńcu fundowany obrócieło się, w którym skaleczeni żołnierze zostawać mają ${ }^{113}$, druga zaś połowa na reparacją kościołów, jako w Dunaygrodzie ${ }^{114}$ tejże majętności, tak też i w Kamieńcu Podolskim ${ }^{115}$ na restauracją zrujnowanych kościołów i klasztorów.

Na zawdzięczenie zaś JMPP egzekutorom, nie mogąc nic tak godnego wynaleźć, z obrazów moich jednak ofiaruję: dla książęcia JM biskupa warmińskiego ${ }^{116}$ Salvatora i drugi Pana Jezusa kuszonego na blasze, JMP podkanclerzemu koron[nem] $\mathrm{u}^{117}$ obraz Pana Jezusa piszącego palcem i drugi obrazek Ś[więtej] Anny Prorokini mały, JM ks[iędzu] sufraganowi krako[w]skiemu ${ }^{118}$ obraz depozycyjej P[ana] Jezusa na płótnie malowany i drugi miniaturowy Ś[więtego] Jacka w ramach złocistych, JMP koniusze-

${ }^{\prime}$ W tym miejscu skreślony wyraz: dla.

111 Por. przyp. 77.

112 Dobra ziemskie Michała Stanisławskiego, ojca poetki, w województwie podolskim (Dunajgród, Hozołubińce, Rzeczyńce) po traktacie buczackim (1672) znalazły się na terenie zajętym przez Turków. Por. M. Nagielski, Stanisławski Michał, s. 123.

113 Szpital dla żołnierzy ufundowany przez ojca poetki w Kamieńcu Podolskim (por. przyp. 114) z dochodami zabezpieczonymi na dobrach Hozołubińce i Rzeczyńce w województwie podolskim. Fundację tę zatwierdził sejm 1667 r. Ibidem, s. 123.

${ }^{114}$ Dunajgród - w końcu XVII w. miasto w województwie podolskim, później nazwę zmieniono na Dunajowce (dziś Дунаївці, Ukraina). Stanisławscy pisali się z Dunajgrodu, zaś ojciec poetki był właścicielem miasteczka. Zob. m.in.: ibidem, s. 122-123.

${ }^{115}$ Kamieniec Podolski (dziś Кам' янець-Подільський, Ukraina) - miasto, stolica województwa.

${ }_{116}$ Por. przyp. 41.

117 Por. przyp. 42.

118 Por. przyp. 43. 
mu ${ }^{119}$ obrazów cztery świeckich, // to jest obraz starca śpiącego, obraz starca grzejącego, obraz satyra, obraz z maszkarka, JM ks[iędzu] probosczowi świętokrzyskiemu warszawskiemu ${ }^{120}$ obraz Wieczerzy Pańskiej na blasze, obraz Magdaleny większy na płótnie, JMP pisarzowi ${ }^{121}$ obraz Zuzanny i obraz Pana Jezusa między doktorami.

Drugie zaś rzeczy ruchome, na osobnym regestrze specyfikowane będa, któremi jako dysponować będą ${ }^{m}$, tymże JMPP egzekutorom daję w moc, prosząc, aby moję wykonali we wszystkim wolą.

Tą tedy ostatnią wolą moję i dyspozycją przy zupełnym i doskonałym rozumie uczynioną i rekolekcyjej, dla lepszej pewności i wagi, przy podpisie JMPP przyjaciół na to umyślnie proszonych, ręką własną przy pieczęci mojej podpisuję, z tą jednak deklaracją że jeżeli by ta ostatnia wola moja dla jaki okoliczności albo defektu nie mogła być ważna jako testament, żeby ważna była jako codicillus albo jakimkolwiek inszym sposobem może być jako najlepi[ej] ugruntowany. Przeto, jakom już upraszała JMPP opiekunów i egzekutorów, tak i teraz powtórnie przez miłość Boską o to upraszam, ażeby we wszystkich pomienionych punktach do woli i intencyjej mojej jako najdoskonali stosować się raczyli, z tą deklaracją że jeżeli by który z JMM dla jakiej przeszkody pracy tej podjąć się albo nie chciał, albo nie mógł, tedy wolno będzie drugim JMPP egzekutorom do wykonania tej ostatniej woli mojej przystąpić i onę do skutku przyprowadzić.

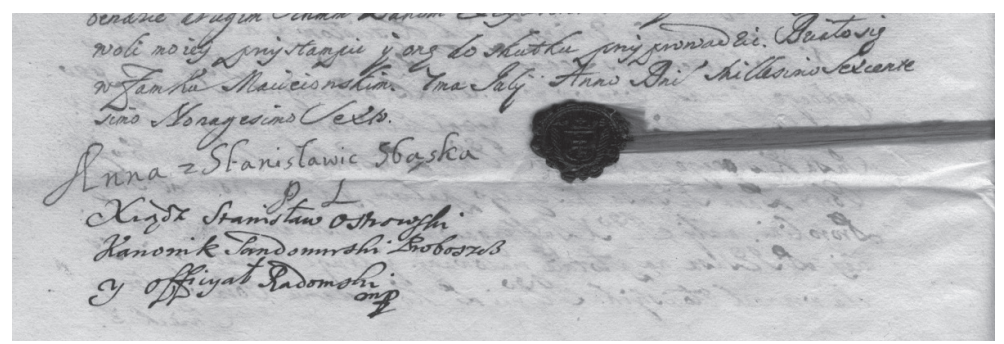

Fot. 1. Fragment ostatniej strony testamentu Anny ze Stanisławskich Zbąskiej z jej podpisem i pieczęcią herbową

Źródło: AN w Krakowie (oddział na Wawelu), Archiwum Podhoreckich IV, sygn. Podh. XXIX, dok. nr 3, nlb.

\footnotetext{
119 Por. przyp. 37.

${ }^{120}$ Por. przyp. 35.

${ }^{121}$ Por. przyp. 46.

m Wyraz nadpisany.
} 
Działo się w zamku macieiowskim ${ }^{122}$ [septi]ma Iulii anno D[omi]ni 1696 [7 VII 1696].

Anna z Stanisławic Sbąska p[odkomorzyna] 1[ubelska] ${ }^{\mathrm{n}}$. Xiądz Stanisław Ostrowski kanonik sandomirski proboszcz i officyał radomski ${ }^{123}$ m.p

\section{BIBLIOGRAFIA (REFERENCES)}

\section{Źródła rękopiśmienne}

Archiwum Narodowe w Krakowie (oddział na Wawelu): Archiwum Podhoreckich IV, sygn. Podh. XII 21/6. Archiwum Podhoreckich IV, sygn. Podh. XXIX, dok. nr 3.

\section{Źródła drukowane}

Biblioteka Polskiej Akademii Nauk w Kórniku, Teki Dworzaczka. Materiały historyczno-genealogiczne do dziejów szlachty wielkopolskiej XV-XX wieku, kier. nauk. J. Wisłocki, Kórnik-Poznań 2004 (online).

Cui contingit nasci, restat mori. Wybór testamentów z województwa sandomierskiego, oprac. M. Lubczyński, J. Pielas, H. Suchojad, Warszawa 2005.

Łaski J., Liber beneficiorum archidioecesis Gnesnensis, t. 2, ed. J. Łukowski, Gnesnae 1881.

Rejestr poborowy województwa lubelskiego (powiat lubelski i urzędowski z r. 1626, ziemia łukowska $z$ r. 1620), oprac. J. Kolasa, K. Schuster, red. S. Inglot, Wrocław 1957.

Stanisławska A., A Transaction, or an Account of the Entire Life of an Orphan Girl by Way of Plaintful Threnodies in the Year 1685. The Aesop Episode, tłum., wstęp i oprac. B. Keane, Warszawa 2013.

Stanisławska A., Transakcyja albo opisanie całego życia jednej sieroty przez żałosne treny od tejże samej pisane roku 1685, wyd. I. Kotowa, w: Biblioteka Pisarzów Polskich, nr 85, Kraków 1935.

Stanisławska A., Transakcyja albo Opisanie całego życia jednej sieroty przez żałosne treny od tejże samej pisane roku 1685. Fragmenty, oprac. P. Borek, Kraków 2003.

Testamenty szlacheckie z ksiag grodzkich wielkopolskich z lat 1681-1700, wyd. P. Klint, Wrocław 2015.

Testamenty szlachty krakowskiej XVII-XVIII w. Wybór tekstów źródłowych z lat 1650-1799, oprac. A. Falniowska-Gradowska, Kraków 1997.

Źródła i materiały do dziejów szlachty województwa sandomierskiego w XVI-XVIII wieku, t. 3: Akty podziałów dóbr ziemskich szlachty sandomierskiej z XVII wieku, wstęp i oprac. J. Pielas, Kielce 2014.

${ }^{122}$ Fakt istnienia wówczas zamku [dworu murowanego? - J.P.] przy miasteczku Maciejowice potwierdza m.in.: SGKP, t. 5, Warszawa 1884, s. 885 („Za obrębem miejskim leżący dawny zamek, zniszczony w czasie bitwy d. 10 października 1794 r. [...]").

${ }^{n}$ Obok podpisu poetki znajduje się pieczęć z czarnego wosku z herbem Pilawa oraz sznurkiem w kolorze zielonym.

${ }^{123}$ Ks. Stanisław Ostrowski (zm. 1700), kanonik sandomierski (1684-1700), proboszcz i oficjał radomski (1693-1700). J. Wiśniewski, Katalog, s. 228; idem, Dekanat radomski, s. 229. 


\section{Opracowania}

Araszkiewicz A., Wierszowany pamiętnik Anny Stanisławskiej, w: Per mulierem... Kobieta $w$ dawnej Polsce - w średniowieczu i w dobie staropolskiej, red. K. Justyniarska-Chojak, S. Konarska-Zimnicka, Warszawa 2012.

Barącz S., Rys dziejów zakonu kaznodziejskiego w Polsce, t. 2, Lwów 1861.

Biedrzycka A., Szyszkowski Mikołaj, w: Polski Słownik Biograficzny, t. 50, Warszawa-Kraków 2015.

Boniecki A., Herbarz polski, t. 1, 12, Warszawa 1899, 1908.

Borkowska M. OSB, Klasztor benedyktynek radomskich i jego rola w życiu religijnym i kulturalnym Radomia i ziemi radomskiej, w: Radom i region radomski w dobie szlacheckiej Rzeczypospolitej, t. 2: Historia społeczno-religijna okresu wczesnonowożytnego, red. Z. Guldon, S. Zieliński, Radom 1996.

Borkowska M. OSB, Leksykon zakonnic polskich epoki przedrozbiorowej, t. 1: Polska Zachodnia i Pótnocna, Warszawa 2004.

Borkowska M. OSB, Leksykon zakonnic polskich epoki przedrozbiorowej, t. 2: Polska Centralna i Potudniowa, Warszawa 2005.

Borkowska M. OSB, Zakony żeńskie w Polsce w epoce nowożytnej, Lublin 2010.

Brückner A., Dzieje literatury polskiej w zarysie, t. 1, Warszawa 1908.

Brückner A., Pierwsza autorka polska i jej autobiografia wierszem, „Biblioteka Warszawska” $1893,4$.

Bursze J., Anna Zbaska ze Stanisławskich, „Rocznik Muzeum Narodowego w Warszawie” 1969, 13.

Chromecki T., Krótki rys dziejów Zgromadzenia Szkót Pobożnych czyli OO. Pijarów, Kraków 1880.

Deputaci Trybunatu Koronnego 1578-1794. Spis, cz. I: 1578-1620, oprac. H. Gmiterek, Warszawa 2017.

Dworzaczek W., Genealogia, cz. 2, Warszawa 1959.

Dygdała J., Tarło Michał Bartłomiej, w: Polski Słownik Biograficzny, t. 52, 2018 [w druku].

Dziechcińska H., Pamiętniki czasów saskich. Od sentymentalizmu do sensualizmu, Bydgoszcz 1999.

Dziechcińska H., Świat i człowiek w pamiętnikach trzech stuleci: XVI-XVII-XVIII, Warszawa 2003.

Dzieje Kalisza, red. W. Rusiński, Poznań 1977.

Gierowski J.A., Koniecpolski Jan Aleksander, w: Polski Słownik Biograficzny, t. 13, WrocławWarszawa-Kraków 1967-1968.

Guldon Z., Kowalski W., Szpitale w województwie sandomierskim w drugiej połowie XVII wieku, „Nasza Przeszłość" 1995, 84.

Instrukcja wydawnicza dla źródet historycznych od XVI do połowy XIX wieku, red. K. Lepszy, Wrocław 1953.

Inwentarz rękopisów Archiwum Kapituły Kolegiackiej i Katedralnej w Sandomierzu XIII-XX wie$k u$, oprac. F. Kiryk, Sandomierz 2010.

Karpiński A., Zapisy „pobożne” i postawy religijne mieszczanek polskich w świetle testamentów $z$ drugiej połowy XVI i XVII w., w: Tryumfy i porażki. Studia z dziejów kultury polskiej XVI-XVIII w., red. M. Bogucka, Warszawa 1989.

Katalogi biskupów poznańskich, oprac. J. Wiesiołowski, Poznań 2004.

Katalog zabytków sztuki w Polsce, t. 4: Miasto Kraków, cz. 3: Kościoty i klasztory śródmieścia 2, red. A. Bochnak, J. Samek, Warszawa 1978.

Katalog zabytków sztuki w Polsce, t. 4: Miasto Kraków, cz. 5: Kazimierz i Stradom. Kościoły i klasztory, red. I. Rejduch-Samkowa, J. Samek, Warszawa 1978.

Keckowa A., Kotowski Adam, w: Polski Słownik Biograficzny, t. 14, Wrocław-Warszawa-Kraków 1968-1969.

Kersten A., Krzysztof Koniecpolski, w: Polski Słownik Biograficzny, t. 13, Warszawa-Kraków 1967-1968. 
Kiryk F., Urbanizacja Małopolski. Województwo sandomierskie XIII-XVI wiek, Kielce 1994.

Korytkowski J., Prataci i kanonicy katedry metropolitalnej gnieźnieńskiej od roku 1000 aż do dni naszych, t. 4, Gniezno 1883.

Kosman M., Między ottarzem a tronem. Poczet prymasów Polski, Poznań 2000.

Kotowa I., Anna Stanisławska, pierwsza autorka polska, „Pamiętnik Literacki” 1934, 31.

Kowalczykowa E., Kościót Św. Krzyża, Warszawa 1975.

Krasny P., Kościót Misjonarzy w Lublinie. Geneza form architektonicznych i problem autorstwa, „Kwartalnik Architektury i Urbanistyki” 1996, 41.

Krzywy R., Pragnienie pamięci i „białogłowski koncept”. Kilka uwag o świadomości warsztatowej pierwszych polskich pamiętnikarek (Anna Zbaska, Regina Salomea Pilsztynowa), „Śląskie Studia Polonistyczne" 2013, 2.

Księga pamiątkowa trzechsetlecia Zgromadzenia Księży Misjonarzy (1625-17/IV-1925), Kraków 1925.

Kuchowicz Z., Wizerunki niepospolitych niewiast staropolskich XVI-XVII wieku, Łódź 1972.

Kumor B.S., Dzieje diecezji krakowskiej do roku 1795, t. 1, Kraków 1998.

Kurczewski J., Biskupstwo wileńskie, Wilno 1912.

Kusiak J., "Jedna sierota" w sarmackim świecie - autoportret Anny Stanisławskiej, w: Gorsza „kobieta": dyskursy, inności, samotności, szaleństwa, red. D. Adamowicz, Y. Anisimovets, O. Taranek, Wrocław 2008.

Link-Lenczowski A.K., Szembek Stanisław, w: Polski Słownik Biograficzny, t. 48, WarszawaKraków 2012-2013.

Łętowski L., Katalog biskupów, pratatów i kanoników krakowskich, t. 4, Kraków 1853.

Marecki J., Kościót i klasztor kapucynów w Krakowie, Kraków 1995.

Mikulski T., Anna Zbąska ze Stanisławskich, „Ruch Literacki” 1935, 10.

Molenda Z., Jubileuszowe dziękczynienie szarytek w Lublinie, „Niedziela” 2002, 10.

Nagielski M., Skarszewski Stanisław, w: Polski Słownik Biograficzny, t. 38, Warszawa-Kraków 1997-1998.

Nagielski M., Stanisławski Michał, w: Polski Słownik Biograficzny, t. 42, Warszawa-Kraków 2003-2004.

Niesiecki K., Herbarz polski, t. 5, 6, 8, wyd. J.N. Bobrowicz, Lipsk 1841.

Nitecki P., Biskupi Kościoła w Polsce. Stownik biograficzny, Warszawa 1992.

Obremski K., O "kobietach, kanonie i badaniach literatury dawnej" głos polemiczny, "Terminus" 2016, 18, 3.

Ożarska M., Combining a Lament with a Verse Memoir. Anna Stanisławska's Transaction' (1685), "Časopis pro slovanskou filologii” 2012, 81, 4.

Partyka J., "Ż̇ona wyćwiczona”. Kobieta piszaca w kulturze XVI i XVII wieku, Warszawa 2004.

Pielas J., Oleśniccy herbu Dębno w XVI-XVII wieku. Studium z dziejów zamożnej szlachty doby nowożytnej, Kielce 2007.

Pielas J., Podziaty majatkowe szlachty koronnej w XVII wieku, Kielce 2013.

Pielas J., Zabezpieczenie praw majątkowych Anny Stanisławskiej w intercyzie przedślubnej z 1669 roku, „Almanach Historyczny" 2000, 2.

Popiołek B., "Na ratunek duszy mojej” - pobożne fundacje w świetle testamentów staropolskich XVII-XVIII wieku, w: Mecenas i fundator. Magnateria Rzeczypospolitej XVI-XVIII wieku, red. E. Dubas-Urwanowicz, J. Urwanowicz, Białystok 2011.

Popiołek B., Polisa na życie wieczne. Zagadnienie miłosierdzia w testamentach czasów saskich, „Nasza Przeszłośćc" 2012, 117.

Popiołek B., Woli mojej ostatniej testament ten... Testamenty staropolskie jako źródło do historii mentalności XVII i XVIII wieku, Kraków 2009.

Popławska H., "Żałosne treny" Anny Stanisławskiej, w: Pisarki polskie epok dawnych, red. K. Stasiewicz, Olsztyn 1988.

Przyałgowski W., Żywoty biskupów wileńskich, t. 3, Petersburg 1860. 
Raciborski J., Monografja Kalisza, cz. 1, Kalisz 1912.

Rott D., Kobieta z przemalowanego portretu. Opowieść o Annie Zbaskiej ze Stanistawskich i jej Transakcyji albo Opisaniu całego życia jednej sieroty [...], Katowice 2004.

Ruszczycówna J., Trzy portrety polskiej poetki XVII wieku (Anna ze Stanistawskich Zbąska), „Rocznik Muzeum Narodowego w Warszawie” 1969, 13.

Sajkowski A., Staropolska miłość. Z dawnych listów i pamiętników, Poznań 1981.

Sajkowski A., Żywoty niepospolitych kobiet polskiego baroku, Łódź 1989.

Schletz A. CM, Ks. Biskup Michał Bartłomiej Tarło opiekun ubogich, „Nasza Przeszłość” 2011, $115-116$.

Schletz A., Historia Sióstr Miłosierdzia w Polsce, „Nasza Przeszłość” 1960, 12.

Słownik Geograficzny Królestwa Polskiego i innych krajów słowiańskich, t. 5, 11, red. B. Chlebowski, Warszawa 1884, 1890.

Sokalski M., Szyszkowski Piotr, w: Polski Słownik Biograficzny, t. 50, Warszawa-Kraków 2015.

Sondel J., Słownik łacińsko-polski dla prawników i historyków, Kraków 1997.

Spież J.A. OP, "Figle i niedole” poddanych dominikańskiego klasztoru pw. Bożego Ciała we Lwowie z majatku w Dawidowie w XVIII w., w: Klasztor w gospodarce średniowiecznej i nowo$\dot{z} y$ tnej, red. M. Derwich, Wrocław 2013.

Staniszewski A.T., Nieobecna "ksią̇ka białogłowskiego konceptu”. Kobiety, kanon i badania literatury dawnej, „Terminus" 2014, 16, 2.

Stankowa M., Ocalałe fragmenty akt Trybunału Koronnego Lubelskiego w Wojewódzkim Archiwum Państwowym w Lublinie 1578-1793, „Archeion” 1964, 40.

Stasiewicz K., Zmysłowa i elokwentna prowincjuszka na staropolskim Parnasie. Rzecz o Elżbiecie Drużbackiej i nie tylko..., Olsztyn 2001.

Szczeblewski S., Klasztor bernardynek kaliskich na podstawie tzw. kaliskiego kopiarza, "Studia Włocławskie" 2016, 18.

Szczęsny S., Anny ze Stanisławskich Zbaskiej opowieść o sobie i mężach. Glosa do barokowej trenodii, w: Pisarki polskie epok dawnych, red. K. Stasiewicz, Olsztyn 1988.

Szylar A., Działalność wychowawczo-edukacyjna żeńskich zgromadzeń zakonnych w Małopolsce w okresie potrydenckim do 1815 r., Kraków 2012.

Targosz K., Damy XVII wieku z piórem w ręku - od listu do autobiografii, w: Pisarki polskie epok dawnych, red. K. Stasiewicz, Olsztyn 1988.

Targosz K., Piórem zakonnicy. Kronikarki w Polsce XVII w. o swoich zakonach i swoich czasach, Kraków 2002.

Targosz K., Sawantki w Polsce XVII w. Aspiracje intelektualne kobiet ze środowisk dworskich, Warszawa 1997.

Uruski S., Rodzina. Herbarz szlachty polskiej, t. 7, wyd. A.A. Kosiński, A. Włodarski, Warszawa 1910.

Urzędnicy centralni i dygnitarze Wielkiego Księstwa Litewskiego XIV-XVIII wieku. Spisy, oprac. H. Lulewicz, A. Rachuba, red. A. Gąsiorowski, Kórnik 1994.

Urzędnicy centralni i nadworni Polski XIV-XVIII wieku. Spisy, oprac. K. Chłapowski et al., red. A. Gąsiorowski, Kórnik 1992.

Urzędnicy wielkopolscy XVI-XVIII wieku. Spisy, oprac. A. Bieniaszewski, red. A. Gąsiorowski, Wrocław 1987.

Urzędnicy województw kijowskiego i czernihowskiego XV-XVIII wieku. Spisy, oprac. E. Janas, W. Kłaczewski, Kórnik 2002.

Urzędnicy województw łęczyckiego i sieradzkiego XVI-XVIII wieku. Spisy, oprac. E. Opaliński, H. Żerek-Kleszcz, red. A. Gąsiorowski, Kórnik 1993.

Urzędnicy województwa krakowskiego XVI-XVIII wieku. Spisy, oprac. S. Cynarski, A. Falniowska-Gradowska, red. A. Gąsiorowski, Kórnik 1990. 
Urzędnicy województwa lubelskiego XVI-XVIII wieku. Spisy, oprac. W. Kłaczewski, W. Urban, red. A. Gąsiorowski, Kórnik 1991.

Urzędnicy województwa ruskiego XIV-XVIII wieku (ziemie halicka, lwowska, przemyska, sanocka). Spisy, oprac. K. Przyboś, Wrocław 1987.

Urzędnicy województwa sandomierskiego XVI-XVIII wieku. Spisy, oprac. K. Chłapowski, A. Falniowska-Gradowska, red. A. Gąsiorowski, Kórnik 1993.

Wanat B.J. OCD, Zakon karmelitów bosych w Polsce. Klasztory karmelitów i karmelitanek bosych 1605-1975, Kraków 1979.

Wierzbicki L.A., Poselstwa od szlachty województwa sandomierskiego do Michała Korybuta i Jana III (1670-1693), w: Z życia politycznego szlachty i ziemiaństwa między Wista a Pilica w XVI-XX wieku. Studia, red. J. Gapys, M. Nowak, J. Pielas, Kielce 2017.

Wieteska J., Katalog pratatów i kanoników kapituły łowickiej od 1433 do 1970, Warszawa 1971.

Wilczyński M., Klasztor świętego Kazimierza oo. reformatów w Krakowie, Kraków 1893.

Wiśniewska H., Świat płci żeńskiej baroku zaklęty w słowach, Lublin 2003.

Wiśniewski J., Dekanat radomski, Radom 1911.

Wiśniewski J., Katalog prałatów i kanoników sandomierskich od 1186 do 1926 r. tudzież sesje kapituty sandomierskiej od 1581 do 1866 r., Radom 1928.

Wróbel E.E., Staropolski autoportret białogłowy, „Folia Historica Cracoviensia” 2011, 17.

Wyczawski H.E. OFM, Klasztory bernardyńskie w Polsce w jej granicach historycznych, Kalwaria Zebrzydowska 1985.

Zielińska K., O trenach Anny Stanisławskiej. Refleksja genologiczna, „Szkice Humanistyczne” 2016, 16, 3.

Zgromadzenie Sióstr Miłosierdzia św. Wincentego á Paulo w Polsce (1652-2002), t. 2, red. A. Dzierżak, S. Motyka, W. Bomba, J. Dukała, Kraków 2002.

\section{Strony internetowe}

http://teatrnn.pl/leksykon/artykuly/kosciol-pw-przemienienia-panskiego-seminaryjny-wlublinie/ [dostęp: 16 I 2018].

http://www.niedziela.pl/artykul/68577/nd/Jubileuszowe-dziekczynienie-Szarytek-w [dostęp: 17 I 2018].

\section{ABSTRACT}

The edited source is an unknown testament of Anna Stanisławska, the first Polish female, drawn up on 7 July 1696. As yet, there is no detailed biography of Anna Stanisławska, the author of the work A Transaction, or an Account of the Entire Life of an Orphan Girl by Way of Plaintful Threnodies in the Year 1685. The published testament brings new information about the last years of her life and activities for the benefit of the Catholic Church, as well as the property she owned. The will reveals the hitherto unknown burial place of the poet in Lublin. At the same time, Anna Stanisławska's last will shows her generosity towards many institutions of the Catholic Church.

Key words: testament, Anna from Stanisławski Zbąska, first female poet, biography, Catholic Church 


\section{NOTA O AUTORZE}

Jacek Pielas - doktor habilitowany, profesor Uniwersytetu Jana Kochanowskiego w Kielcach. Stopień doktora otrzymał w 2001 r. na podstawie rozprawy Oleśniccy herbu Dębno w XVI-XVII wieku. Studium z dziejów zamożnej szlachty doby nowożytnej, habilitację zaś uzyskał w 2014 r. na podstawie książki Podziały majątkowe szlachty koronnej w XVII wieku (Kielce 2013). Do jego ważniejszych publikacji można zaliczyć następujące tytuły: Oleśniccy herbu Dębno w XVI-XVII wieku. Studium z dziejów zamożnej szlachty doby nowożytnej (Kielce 2007); Źródta i materiaty do dziejów szlachty województwa sandomierskiego w XVI-XVIII wieku, t. 1: Rejestry pospolitego ruszenia szlachty sandomierskiej z XVII wieku, wstęp i oprac. J. Pielas (Kielce 2009); Podziały majątkowe szlachty koronnej w XVII wieku (Kielce 2013); Źródła i materiały do dziejów szlachty województwa sandomierskiego w XVI-XVIII wieku, t. 2: Inwentarze dóbr ziemskich z XVII-XVIII wieku, cz. 1 (Kielce 2013); Źródła i materiały do dziejów szlachty województwa sandomierskiego w XVI-XVIII wieku, t. 3: Akty podziałów dóbr ziemskich szlachty sandomierskiej z XVII wieku, wstęp i oprac. J. Pielas (Kielce 2014); Źródta i materiały do dziejów szlachty województwa sandomierskiego w XVI-XVIII wieku, t. 2: Inwentarze dóbr ziemskich z XVII-XVIII wieku, cz. 2, wstęp i oprac. K. Justyniarska-Chojak, J. Pielas (Kielce 2016). Zainteresowania badawcze Autora skupiają się na następujących zagadnieniach: struktura społeczna i struktura własności szlachty koronnej w XVI-XVIII w., elity majątkowe i polityczne w Małopolsce w XVI-XVII w., spadkobrania szlacheckie w Koronie w XVII w., genealogia i majątki szlachty województwa sandomierskiego w XVI-XVIII w., życie codzienne szlachty polskiej, rodzina szlachecka i jej funkcjonowanie w okresie nowożytnym. E-mail: jacek.pielas@ujk.edu.pl 